\title{
Farklı Bakış Açılarıyla Okul Öncesi Eğitimde Kalite Unsurları: Nitel Bir Araştırma
}

\section{Abdulhamit Karademir ${ }^{1}$}

\author{
Berrin Akman²
}

\section{Type/Tür:}

Research/Araştırma

Received/Geliş Tarihi: March

17/ 17 Mart 2020

Accepted/Kabul Tarihi: August

13/ 13 Ağustos 2020

Page numbers/Sayfa No: 181-206

Corresponding

Author/İletişimden Sorumlu

Yazar:

a.karademir@alparslan.edu.tr

\section{$\checkmark$ iThenticate}

This paper was checked for plagiarism using iThenticate during the preview process and before publication. / Bu çalışma ön inceleme sürecinde ve yayımlanmadan önce iThenticate yazılımı ile taranmıştır.

Copyright $(92017$ by

Cumhuriyet University, Faculty of Education. All rights reserved.

\section{Öz}

Erken çocukluk eğitim hizmetlerinde kalite; fiziksel çevre ve materyal, öğretmen ve ilgili personel yeterlilikleri, sınıftaki çocuk sayısı, öğretmen başına düşen çocuk sayısı, öğretmen ve çocuk etkileşimleri, uygulanan program, iletişim ve aile eğitimi ve katılımı gibi faktörlerden etkilenmektedir. Erken çocukluk dönemi eğitimcileri ve araştırmacılar, eğitim hizmetlerinin iyi düzenlenmiş ortamlarda, kaliteli öğretmenler ve personel tarafından yürütülmesinin çocukların erken öğrenmelerini destekleyici nitelikte olduğunu belirtmektedirler. Bu görüşten yola çıkarak bu araştırmada anasınıflarında ve anaokullarında görev yapmakta olan öğretmenlerin ve kurum yöneticilerinin erken çocukluk eğitiminde kalite hakkındaki düşünceleri belirlenmeye çalışılmıştır. Nitel araştırma türlerinden durum çalışması olarak tasarlanan araştırma Muş ili merkez ilçesindeki sekiz okulda 2019-2020 eğitim-öğretim yılında gerçekleştirilmiştir. Çalışma grubunu amaçlı örneklem biçimlerinden ulaşılabilir örneklem ile seçilen Milli Eğitim Bakanlığı'na bağlı resmi beş ilkokulda görev yapan altı okul öncesi öğretmeni ve beş yönetici ile Milli Eğitim Bakanlığı'na bağlı resmi dört anaokulunda görev yapan altı okul öncesi öğretmeni ve dört yönetici oluşturmuştur. Araştırma kapsamında belirlenen kişilere yarı yapılandırılmış görüşme tekniği ile dokuz tane soru yöneltilerek bu sorular hakkındaki görüşleri alınmıştır. Araştırmanın sonuçları tümevarımsal içerik analizi tekniği kullanılarak analiz edilmiştir. Okul öncesi eğitimde kaliteye yönelik farklı bakış açılarını karşılaştırmak amacıyla yapılan bu araştırma sonucunda; kalitenin fiziksel koşullar yanında öğretmen niteliği ve eğitim-öğretim hizmetleri içeriğiyle doğrudan, çocuklara kazandırılmak istenen olumlu tutum alışkanlıkların ise dolaylı olarak ilişkili olduğu bulunmuştur.

Anahtar Kelimeler: Okul öncesi eğitim, erken çocukluk eğitiminde kalite, etkileşim, öğretmenler, yöneticiler.

\section{Suggested APA Citation/Önerilen APA Atıf Biçimi:}

Karademir, A., \& Akman, B. (2021). Farklı bakış açllarıyla okul öncesi eğitimde kalite unsurları: Nitel bir araştırma. Cumhuriyet International Journal of Education, 10(1), 181-206. http://dx.doi.org/10.30703/cije.704925

\footnotetext{
1 Dr. Öğr. Üyesi, Muş Alparslan Üniversitesi, Eğitim Fakültesi, Temel Eğitim Bölümü, Muş/Türkiye Assist. Prof. Dr., Mus Alparslan University, Faculty of Education, Department of Basic Education, Mus/Turkey e-mail: a.karademir@alparslan.edu.tr ORCID ID: orcid.org/ 0000-0003-3062-8547

2 Prof. Dr., Hacettepe Üniversitesi, Eğitim Fakültesi, Temel Eğitim Bölümü, Ankara/Türkiye Prof. Dr., Hacettepe University, Faculty of Education, Department of Basic Education, Ankara/Turkey e-mail: bakman@hacettepe.edu.tr ORCID ID: orcid.org/ 0000-0001-5668-4382
} 


\title{
Quality Elements in Preschool Education with Different Perspectives: A Qualitative Research
}

\begin{abstract}
Quality in early childhood education services; are affected by factors such as the physical environment and material, teacher and related personnel competencies, the number of children in the classroom, the number of children per teacher, teacher and child interactions, program, communication, and family education and participation. Early childhood educators and researchers state that the provision of educational services in well-organized settings by qualified teachers and staff support children's early learning. Based on this view, in this research, the opinions of teachers, in-class assistant staff and institution managers working in nursery classes and kindergartens about quality in early childhood education were tried to be determined. The research, which was designed as a case study, is carried out in the central district of Muş in the 2019-2020 academic year. Six pre-school teachers and five administrators working at four primary schools and also six pre-school teachers and four administrators working at four kindergartens affiliated to the Ministry of National Education, selected by the sample of which the study the group could be accessed from the purposeful sampling forms. Nine questions were asked to the people determined within the scope of the research with semi-structured interview technique and their opinions about these questions were taken. The results of the research were analyzed using the inductive content analysis technique. As a result of this research conducted to compare different perspectives on quality in preschool education; besides physical conditions, the quality was found to be directly related to the quality of the teacher and the content of education and training services, and the positive attitude habits desired to be given to the children were indirectly related.
\end{abstract}

Keywords: Preschool education, quality in early childhood education, interactions, teachers, administrators

\section{Giriş}

Son y1llarda ülkemizde okul öncesi eğitime verilen önem, toplumsal bilinçlenmeyle birlikte bilimsel çalışmalara ulaşılabilirlik ve takibin artması, ebeveynlik stillerinin ve yaşam biçiminin değişmek zorunda kalması gibi nedenlerle hızlı bir ivme kazanmıştır. İnsanlar çocuklarının daha nitelikli ve geleceğe dönük eğitimler almasını beklemektedirler. Bu nedenle eğitimlerin gerçekleştirildiği kurumların fiziksel yapıları, sahip oldukları olanaklar, sınıflarda bulundurdukları çocuk sayıları, çalıştırdıkları öğretmen nitelikleri, çocuklara kazandırılması düşünülen davranış ve beceriler, ailelerle etkileşim biçimleri vb birçok faktörün öne çıkmaya başladiğ hissedilmektedir (A ğgül Yalçın ve Yalçın, 2018). Yapılan araştırmalarda çocuklardaki gelişimin istenilen düzeyde olması ve çocuğun okul öncesi dönemde verilen eğitimden olumlu etkilenerek geleceğini doğru şekillendirebilmesi için bazı kriterlerin önemi vurgulanmıştır (Can ve Kılıç, 2019; Karademir ve Ören, 2020). Bunlar: iyi eğitimli öğretmenler, sağlıklı çocuk-öğretmen etkileşimi, sınıftaki çocuk sayıs1, dil gelişimini destekleyici güvenli ve materyalce zengin bir ortam, farklı sosyal etkinlikleri barındıran programa uygun uygulamalardır. Araştırma sonuçlarında ayrıca nitelikten ödün verilen eğitim sisteminin gelişim için faydalı olmadığı hatta çocuklara zarar verebileceği ortaya konmuştur (AÇEV, 2009). Ülkemiz erken çocukluk eğitimi sisteminde niteliksel sorunların olduğu bilinmektedir (ERG, 2008; Gür ve Çelik, 2009; TED, 2007; TÜSİAD, 2005). Bu nedenle erken çocukluk eğitimi kurumlarının kalitesinin belirlenmesi ve erken çocukluk 
eğitimindeki kalite standartlarının arttırılması çocuğun gelişimine önemli katkılarda bulunacaktır. Kalite standartları erken çocukluk eğitimi alanına yönelik sosyal politikaların geliştirilmesine ve toplumsal gelişime de katkıda sağlayacaktır (Karademir, Cingi, Dereli ve Akman, 2017; Micozkadıoğlu ve Kazak Berument, 2003). Ancak erken çocukluk eğitiminde kaliteyi çok yönlü düşünmek gerekir. Belirlenen eğitim düzeyinde sisteme genelden özele bakmak önemlidir. Politika yapanlardan başlayan bu yapı, sınıf içerisinde çocuklara kadar inmektedir (Karademir ve Ören, 2020). Sadece çocuğun eğitim aldığı ortam ve çevresel olanaklar kaliteyi açıklamakta yetersiz kalmaktadır. Aksine erken çocukluk eğitimi kurumlarında kalitenin arttırılması için odaklanılması gereken bütüncül standartlar; eğitim programı, etkinliklerin gerçekleştirileceği ortamın niteliği ve niceliği, personel kalitesi, aile ve toplumsal katılım, çocuğun ve eğitim programının değerlendirilmesini kapsamalıdır (Biehl, 2011).

Erken çocukluk dönemi eğitiminde önemli sorulardan biri de yüksek kalite standartlarına sahip bir eğitime çocukların nasıl ulaşabileceğidir. Erken çocukluk eğitimi hizmetlerinde kaliteli bir eğitim sağlanması amacıyla birçok kalite unsuru belirlenmeye çalışılmıştır. Bu bağlamda erken çocukluk eğitimi hizmetlerinde kalite; fiziksel çevre ve materyal, öğretmen ve ilgili personel yeterlilikleri, sınıftaki çocuk sayısı, öğretmen başına düşen çocuk sayısı, öğretmen ve çocuk etkileşimleri, uygulanan program, iletişim, aile eğitimi ve katılımı gibi faktörlerden etkilenmektedir (Karademir ve Ören, 2020). İyi bir çalışma atmosferi de kaliteli eğitimin bileşenidir (Epinosa, 2002; Aydagül, 2009; Wertfein, Spies-Kofler ve BeckerStoll, 2009). Kalite standartları sadece çocukların gelişim ve öğrenmelerini etkilemekle kalmaz bununla birlikte eğitim sistemi, okul ve toplum kültürü ve son olarak da ulusal eğitim politikalarını ciddi bir şekilde etkilemektedir (Logan, Press ve Sumsion, 2012).

OECD erken çocukluk eğitiminde kaliteyi arttırmak için beş temel bileşene odaklanır. Bunlar aşağıdaki gibi ifade edilmiştir (Taguma ve Makowiecki, 2012).

- Kalite amaçları ve minimum standardın belirlenmesi

- Müfredat ve pedagoji

- Personel kalitesi, eğitim ve çalışma koşulları

- Aile ve toplum katılımı

- Araştırma, gözlemleme ve değerlendirme

Bütün çocuklara eşit ve nitelikli bir erken çocukluk eğitiminin sunulması için erken çocukluk eğitimi veren bütün eğitim kurumlarının bir kalite güvence çerçevesi oluşturması ve bu güvence çerçevenin asgari koşullarını sağlaması eğitimin kalitesini arttıracaktır (Dünya Bankası İnsani Kalkınma Departmanı [DBİKD], 2011). Erken çocukluk eğitiminde kalite standartları belirlenirken bütün paydaşların görüş ve önerilerine başvurulmalıdır. Bu görüş ve öneriler doğrultusunda kalite standartları belirlenmelidir (Güleş ve Erişen, 2013). Okulda çocuklara yönelik uygulanan eğitim programı çocuğun gelişim alanlarını destekleyen, çocuğun yararını gözeten, çağın gereklerini karşılayan, aile ve toplum katılımını teşvik eden, demokratik ve çok kültürlü bir yapıya sahip bir programdır (MEB, 2018; Zan, 2005). Yüksek standartlarda erken çocukluk eğitimi için bu alanda hizmet yapacak bütün personelin iyi bir eğitim alması, bu personelin sürekli profesyonel anlamda gelişime açık olması, personelin çalışma koşullarının ve özlük haklarının iyi olması 
gerekmektedir (ISSA, 2010a). Bununla birlikte kalite standartları yüksek erken çocukluk eğitim kurumları çocuğun gelişimi ve öğrenmesini en iyi şekilde destekleyen, aile ve toplum katılımını teşvik eden bir öğrenme ortamı içerir (Jalongo vd., 2004). Erken çocukluk dönemi eğitiminde ailenin çocuğun gelişimi üzerindeki etkisi göz önüne alındığında kurumda çocuğun evdeki etkileşimi ve iletişiminin kalitesinin arttırılması için de çeşitli faaliyetler yapılmalıdır (Aydagül, 2009). Ailenin eğitsel faaliyetlere ve yönetimsel kararlara katılımları teşvik edilmelidir. Erken çocukluk eğitiminde kaliteyi arttırmak için eğitim alanında çalışan sivil toplum kuruluşları eğitime daha fazla destek vermeleri için cesaretlendirilmelidir. Ayrıca nitelikli ve kaliteli bir erken çocukluk programı geliştirilmeli ve bu program ülkenin her yerinde uygulanabilir ve ulaşılabilir bir program olmalıdır (The World Bank, 2013).

Öğrenme ortamlarında akran etkileşimi ve öğrenmesi önemli bir yer tutar. Erken çocukluk eğitim kurumlarında fiziksel çevre olanakları çocuğun gelişimini desteklemeli, güvenli olmalı, çocuğun merakını ve keşfetme isteğini arttırmalı, çocuğun yaratıcılığına katkıda bulunmalı ve çocuğa sosyal destek sağlamalıdır. Fiziksel ortamda kullanılan materyallerde çocuğun eğitiminde hedeflenen çıtılar doğrultusunda düzenlenmelidir (Jalongo vd., 2004).

Öğretmen yetiştirmede yeni politikaların belirlenmesi ve öğretmenlere verilen eğitimin daha nitelikli bir hale getirilmesi kalite standartlarını yükseltecektir. ISSA (International Step by Step Association ) (2010b)'a göre postmodern çağda nitelikli ve kaliteli öğretmenin, çocuğun gelişimine ve öğrenmesine katkıda bulunabilmesi için aşağıdaki alanlarda kendini yetiştirmesi gerekmektedir.

- İletişim ve Etkileşim

- Aile ve Toplum Katılımı

- Katılım, Çoğulculuk ve Demokratik Değerler

- Değerlendirme ve Planlama

- Öğretim Stratejileri

- Öğrenme Çevresi

$>$ Profesyonel Gelişim

DBİKD (2011) tarafından yapılan araştırmada gelişmekte olan bazı ülkelerin yakın gelecekte eğitimin kalitesi açısından ciddi sorunlarla karşılaşacağı ifade edilmektedir. Erken çocukluk eğitiminde belli standartların olmadığ1 ve bölgeler arasında eğitime yönelik kalite standartlarının büyük oranda farklılık gösterdiği tespit edilmiştir (Can ve Kılıç, 2019). Bu durum eğitimde eşitlik ve herkesin eğitime ulaşma hakkına engel teşkil ettiği gibi ülkenin büyüme ve gelişmesine de engel olmaktadır. Okul Öncesi Eğitim Süreci İç Denetim Raporu (2010)'nda da benzer olarak okul öncesi eğitim kurumlarında fiziksel çevrenin iyi olmadığı ve nitelikli materyal içermediği, performans değerlendirmesinin olmadığı, yönetimsel fonksiyonların yeterince işlemediği, kaliteli okul öncesi eğitimin her yere eşit ve dengeli bir şekilde ulaşmadığı, insan gücünün etkili ve verimli şekilde kullanılamadığı ve erken çocukluk eğitimi alanında AR-GE çalışmalarının yetersiz olduğu ifade edilmiştir (Demircan Aydın, 2017; Ertör ve Durdağı, 2016; Köksal, Balaban Dağal ve Duman, 2016; Kurşunlu, 2018; On Birinci Kalkınma Planı, 2019; Sildir ve Temiz, 2017; Tükel, 2017). 
İyi eğitim almış kaliteli bir öğretmen, daha az eğitimli öğretmene göre çocuklara gelişim dönemlerine daha uygun hizmetler vermekte, çocukların ihtiyaçlarını daha iyi anlamakta ve bu ihtiyaçları daha profesyonel bir şekilde kısa sürede karşılamaktayken (Burchinal, Cryer, Clifford ve Howes, 2002; Early ve Winton, 2001) ev temelli eğitimlerde aile bireyleriyle kurulan ilişkiler boyutunda daha az sıkıntı yaşamaktadır. Bu durum özellikle sosyo-ekonomik açıdan dezavantajlı toplumlarda çocuklara daha kaliteli okula hazırlık ve erken çocukluk eğitimi alma olanağı tanımaktadır. Bu durumdaki çocukların özellikle bilişsel ve sosyal duygusal gelişim açısından diğer akranları gibi gelişimleri kaliteli öğretmenlerle istenen nitelikte, etkili ve istikrarlı biçimde sağlanabilmektedir (Loeb, Fuller, Kagan, ve Carrol, 2004). Her koşuldaki çocuklar için, içinde bulunulan duruma göre destekleyici bir erken çocukluk eğitimi atmosferinin sağlanması, öğretmen yeterliliklerine bağlıdır. Bu yeterliliklerin kazanılması da, öğretmenlerin iyi ve kaliteli eğitim almalarına bağlanmakta ve en azından üniversitelerin eğitim fakültelerinden mezun olmalarını gerekli kılmaktadır (Whitebook, 2003).

Kaliteli bir erken çocukluk eğitimi, kurumda bulunan kaliteli eğitim almış bir ekiple gerçekleştirilebilmektedir. Alan yazın incelendiğinde kaliteli bir erken çocukluk eğitiminde öğretmenin yeterliliklerinden ve eğitim durumlarından bahsedilen çalışmalar olmasına rağmen (LoCasale-Crouch vd., 2007); kaliteli eğitim ekibi içerisinde yer alan yardımcı öğretmenlerin sahip olması gereken yeterliliklerden bahsedilen çalışmalar nadirdir.

Yardımcı öğretmenler, usta öğreticiler, sınıf annesi veya bakıcı anne gibi birçok adı bulunan sınıf/öğretmen yardımcılarının tanımı şu şekildedir: Sınıf içerisinde öğretmenlerin kontrolü altında öğrencilerle çalışan eğitim personelidir. Yardımcı öğretmenler, sınıf içerisinde öğretmenlerle birlikte eğitim etkinliklerini düzenleme, çocuklarla grup çalışmalarında birebir ilgilenme ve çocukların bakım ihtiyaçlarına yardımcı olmaya kadar birçok görev yürütmektedirler. Okulda ve sınıf içerisinde pek çok görev yapan yardımcı öğretmenlerin sahip olması gereken eğitim konusunda araştırmacıların ve yöneticilerin konuya dâhil olmadığı gözlenmektedir. Türkiye'deki Okul Öncesi Eğitim Kurumları Yönetmeliği'ne göre, hiçbir kurumda öğretmenlere yardımcı olacak bir personel çalıştırma zorunluluğu yoktur. Öğretmenlerin yükünü azaltmak ve bakım hizmetlerine yardımcı olmak için çalıştırılan yardımcı öğretmenler birçok ülkede çalıştırılmaktadır. Örneğin Amerika Birleşik Devletleri'nde okulların hemen hepsinde bir tane yardımcı öğretmen çalışırken, sınıftaki çocuk sayısına bağlı olarak birden fazla da yardımcı öğretmen istihdam edildiği göze çarpmaktadır (Sosinsky ve Gilliam, 2011).

Erken çocukluk eğitiminde çocukların yüksek kalite standartlarına sahip bir eğitim alabilmeleri için çocuğun eğitiminde yer alan bütün paydaşların bu konuda farkındalık sahibi olması gerekir. Literatürde de ifade edildiği gibi erken çocukluk eğitiminde kaliteyi oluşturan en önemli unsurlardan biri de kurumlarda görevli personellerdir. $\mathrm{Bu}$ unsur dikkate alınarak araştırmada erken çocukluk eğitimi alanında görev yapmakta olan yönetici ve öğretmenlerin bakış açısından okulöncesi eğitimde kaliteyi ve yardımcı personellerin kaliteye etkisini belirleyerek, kalitenin eğitim öğretime yansımalarını onların görüşleriyle ortaya konulması amaçlanmıştır.

Bu amaç doğrultusunda aşağıdaki sorulara yanıt aranmıştır:

1. Katılımcılara göre okul öncesi eğitimde kalite nedir? 
2. Katılımcılara göre kaliteyi oluşturan öğeler nelerdir?

3. Öğretmen ve yöneticilere göre yardımcı personel kimdir?

\section{Yöntem}

Araştırma, nitel araştırma türlerinden durum çalışması olarak tasarlanmıştır. İç içe geçmiş tek durum deseninde gerçekleştirilen araştırmada, okul öncesi eğitim kurumlarında görevli öğretmen ve yöneticilerin bütüncül olarak kaliteye ilişkin görüşleri karşılaştırılmak istenmiştir. Güncel bir olguyu kendi gerçek yaşam çerçevesinde ele alan araştırmalarda durum çalışması kullanılabilir (Yıldırım ve Şimsek, 2012). Araştırmada yarı yapılandırılmış görüşme tekniği kullanılmıştır.

\section{Katılımcilar}

Araştırmanın çalışma grubunu Muş ili merkez ilçesinde Milli Eğitim Bakanlığı'na bağlı beş ilkokulun anasınıflarında görev yapan altı okul öncesi öğretmeni ve beş yönetici ile aynı ilçede bulunan Milli Eğitim Bakanlığı' na bağlı dört ana okulda görev yapan altı okul öncesi öğretmeni ve dört yönetici toplamda 21 kişi oluşturmaktadır. Çalışma grubuna dâhil edilen öğretmen ve yönetici belirlenmesinde kolay erişilebilirlik ve çalışmaya katılım için gönüllülük ölçütleri esas alınmıştır. Öğretmenlerin tamamı kadın iken beş ilköğretim okulu yöneticisi de erkektir. Yaş ortalaması $(M=32)$ olarak hesaplanan öğretmenlerin tamamı okul öncesi eğitimi lisans mezunudur. Yaş ortalamaları $(M=39)$ olan kurum yöneticilerinden ilköğretim okullarında görevli olanlar, eğitim fakültelerinin farklı lisans bölümlerinden mezun olmuşlardır. 7 öğretmenin görevinde 10-18 yıl çalıştı̆̆ı, 5 öğretmenin 5-9 yıl çalıştığ1 bilgisi edinilmiştir.

\section{Verilerin Toplanması}

Araştırmada veri toplamak amacıyla öğretmen ve yönetici ile yarı yapılandırılmış görüşme formu kullanılmıştır. Görüşmeler için araştırmacılar tarafından öğretmen ve yönetici için "yarı yapılandırılmış görüşme soruları" oluşturulmuştur. Yarı yapılandırılmış görüşme tekniği kullanılarak yapılan bu görüşmelerde öğretmenler ve yöneticilerin her birine üçer tane soru yöneltilmiştir. Görüşme sorularının hazırlanması sürecinde öncelikle ilgili literatür taranmıştır. Erken çocukluk eğitimi içerisinde yer alan ilgili personelin kalite hakkındaki görüşlerini tanımlayabilecek unsurlar belirlenmiştir. Oluşturulan görüşme formları iki alan uzmanının görüşüne sunularak önerileri alınmış ve bu öneriler doğrultusunda gerekli düzenlenmeler yapılmıştır.

Araştırmacılar tarafından, çalışma kapsamına alınan okullara 2019-2020 eğitim-öğretim yarıyılı güz döneminde gidilmiş ve öğretmenler ve yöneticiler ile ön görüşmeler belirlenen saatte kurumların uygun, sessiz bir alanında yüz yüze yapılarak, çalışmanın amacı ve öneminden söz edilmiştir. Sorular yöneltilerek ilgili öğretmenler ve yöneticilerle birebir görüşmeler yapılmıştır. Görüşmelerden elde edilen veriler katılımcılardan gerekli izinler alınarak araştırmacılar tarafından ses kayıt cihazı ile kaydedilerek veri kaybının önüne geçilmesi sağlanmıştır. Çalışma için gerekli olan etik kurul izni Muş Alparslan Üniversitesi Bilimsel Araştırma ve Yayın Etiği Kurulundan 04.03.2020 tarihli ve 10879717-050.01.04 sayılı yazıyla alınmıştır. 


\section{Verilerin Analizi}

Verilerin kodlanması amacıyla; araştırmacılara genel fikir vermesi için önce tüm görüşme dökümlerinin tamamı birkaç kez okunmuştur. Ardından araştırmanın alt amaçları göz önünde bulundurularak, görüşme verilerinden kodlamalar yapılmıştır. Yapılan kodlamalardan alt temalar ve temalar oluşturularak bulgular tanımlanmış ve yorumlanarak ifade edilmeye çalışılmıştır. Güvenirliliğinin sağlanması amacıyla ise tüm veri kodlamaları yapıldıktan sonra üçüncü bir uzman tarafından kod ve temalar gözden geçirilmiş, verilerin son biçimleri fikir birliği sağlanarak tablolar halinde sunulmuştur.

Araştırma verilerinin çözümlenmesinde tümevarımsal içerik analizi tekniğinden yararlanılmıştır. Tümevarımsal içerik analizi, görüşme yoluyla katılımcılardan elde edilen verilerin, grubun sembolik dünyasını anlamak amacıyla; kodlama yaparak verileri kategorilere ayırma, bu kategoriler arasındaki ilişkileri çıkararak tema ve alt temaları oluşturma şeklinde tanımlanabilir (Patton, 2014). Kodlamalar yapılırken araştırma sorusuna yanıt vereceği düşünülen tüm görüşler ve kayıtlar aynı kod altında birleştirilmiştir. Yapılan kodlamalardan alt temalar ve temalar oluşturulmuştur. Temalar ve alt temalar oluşturulduktan sonra tüm temalar ve alt temalar tekrar gözden geçirilmiş ve birbirleriyle ilişkili olduğu düşünülenler birleştirilmiştir. Temalar ve alt temalara son hali verilmeden önce temaların, alt temaların ve kodların içinde bulunan alıntılar-kayıtlar okunarak kod, alt tema ve temaya uygunluğu kontrol edilmiştir. Çalışmada araştırmacılar tüm kodlama işlemlerini QSR-Nvivo 8 paket programı ile gerçekleşmişlerdir.

Bunun yanında araştırmada, verilerin güvenirliğinin sağlanması amacıyla çeşitli stratejiler belirlenmiştir. İlk olarak, görüşme formlarında aynı amaca yönelik olarak hazırlanmış sorular hem öğretmene hem de yöneticilere sorulmuştur. İkinci olarak, araştırmacıdan bağımsız farklı bir kodlayıcının verilerin \%20'lik bir kısmını analiz etmesi sağlanmıştır. Bu süreçte araştırmacı ve ikinci kodlayıcı birbirlerinden bağımsız şekilde verilerin analizini gerçekleştirmişlerdir. Ardından her iki kodlayıcı kodlarını ve temalarını karşılaştırıp ortak noktada buluşarak birlikte öğretmen ve yöneticiler için tek bir veri kodlama anahtarı oluşturmuşlardır. Daha sonra üçüncü bir uzmana, son hali verilmiş veri kodlama anahtarı ile görüşme dökümlerinden rastgele seçilmiş 3 kişinin görüşme formu verilmiş ve görüşmeleri analiz etmesi istenmiştir. Daha sonra kodlayıcılar arasında Miles ve Huberman'ın (1994) uyuşum yüzdesi formülü uygulanmıştır. Bu bağlamda, araştırmacı ile diğer kodlayıcı arasında, ebeveynlerle yapılan 3 görüşme formunun güvenirliği sırasılyla .87, .86, ve .89 olarak hesaplanmıştır.

\section{Araştırmanın Etik İzinleri}

Yapılan bu çalışmada "Yükseköğretim Kurumları Bilimsel Araştırma ve Yayın Etiği Yönergesi" kapsamında uyulması belirtilen tüm kurallara uyulmuştur. Yönergenin ikinci bölümü olan “Bilimsel Araştırma ve Yayın Etiğine Aykırı Eylemler” başlığı altında belirtilen eylemlerden hiçbiri gerçekleştirilmemiştir.

Etik kurul izin bilgileri

Etik değerlendirmeyi yapan kurul ad1= Muş Alparslan Üniversitesi Bilimsel Araştırma ve Yayın Etiği Kurulu

Etik değerlendirme kararının tarihi=04.03.2020

Etik değerlendirme belgesi sayı numarası = 10879717-050.01.04 


\section{Bulgular}

Bu bölümde anasınıflarında görev yapan altı okul öncesi öğretmeni ve beş yönetici ile anaokullarında görev yapan altı okul öncesi öğretmeni ve dört yöneticiden gönüllü olanlarla yapılan yarı yapılandırılmış görüşmelerden elde edilen bulgular ve bu bulgular doğrultusunda yapılan yorumlara yer verilmiştir. Bulgularda öğretmenlerin ve yöneticilerin verdikleri cevaplara göre kategoriler oluşturulmuştur.

\section{Erken Çocukluk Eğitiminde Kalite nedir?" Sorusuna İlişkin Bulgular}

Okul öncesi öğretmenleri ve okul yöneticilere sorulan “Erken Çocukluk eğitiminde kalite nedir? "sorusunun katılımcılar tarafından birden fazla örnekle açıklandığı görülmektedir.

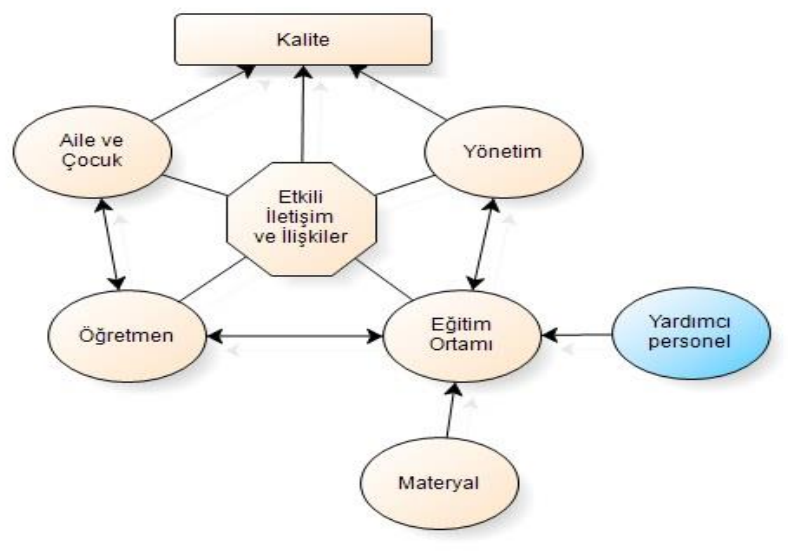

Şekil 1: Kalite tanımına ilişkin görüşler

Öğretmenlerle yapılan görüşmelerin analizleri sonucunda kalite tanımlarına ait alt temalar; "çocukların mutlu olması, öğretmenin kaliteli olması, alandaki yeniliklerin takip edilmesi, sınıfın fiziki şartlarının iyi olması, sınıf içerisinde yardımcının bulunması, nitelikli materyallerin olması, aile eğitimlerinin olması, aile öğretmen etkileşiminin olması, okul yönetiminin destek sunması, çocuğun bütün gelişim alanlarının desteklenmesi" olarak belirlenmiştir. Kalitenin kendileri için ne ifade ettiği sorulan öğretmenlerin büyük çoğunluğunun yanıtlarını çocukların ihtiyaçlarını ve gelişim özelliklerini dikkate alarak verdikleri ayrıca kaliteyi verilen eğitimle özdeşleştirerek birlikte kullandıkları görülmüştür. Anaokullarında görev yapan öğretmenlerin ise kaliteyi daha çok fiziki ortam kalitesi ve öğretmenin kalitesi şeklinde tanımladıkları görülmüştür. Anaokullarında bu iki kalite unsurunun anasınıflarına göre daha iyi bir durumda olduğunu ifade etmişlerdir.

Okulöncesi eğitim döneminin, eğitim kademelerinin en önemlisi olduğunu ve değerinin yeni yeni anlaşılmaya başlandığını belirtip, bu kurumlarda kalitenin oluşması için birçok etmenin bir arada bulunması gerektiğine inanan Ö1 düşüncelerini şöyle aktarmıştır:

Kalite deyince birçok etmenler işin içine giriyor, ilk başta öğretmenlerin yetiştirilmesi, aldığı eğitim, kendini güncellemesi. Günlük yayınları takip etmesi, interneti kullanabilmesi bu kaliteyi etkiler. Bunun dişında özellikle okul öncesi eğitimde sınıfın fiziki koşulları çok önemli. Fiziki koşullar deyince; sınıfın temizliğinden tutun aydınlığına kadar, sınıfta çocuk başına düşecek metre kare alanı, tuvaletinin olup olmaması, bir yardımcının olup olmaması ve elinin altında nitelikli oyuncakların özellikle merkezlerde kullanabileceği özel oyuncakların olası da 
kaliteyi etkiler, bunun dişında aile çok önemli bir faktördür. Çünkü biz aileleri de eğitiyoruz. Eğitimli ailelerin çocukları daha farklı oluyor daha ilgili oluyorlar çünkü çocukları ile ne yapıldığını daha iyi anlayıp kavrayabiliyorlar. Bir de aileler öğretmenlere ne kadar arka çıkarsa desteklerse öğretmenler de daha çok adım atıyor. Bir de okul idaresi var. İdarecilerin anasınıfına bakışı, anasınıfının önemi, inanır mısınız daha ana sınıfının önemini bilmeyen idarecilerle de karşılaşıyoruz. Ama bu işten hiçbir anlamayan idarecimiz olursa işimiz baya zor oluyor. Bunun dişında en büyük sıkıntımız kalabalık sınıflarda yardımcı personelin olup olmaması. Kesinlikle bakanlık ana sınıflarında kadrolu bir yardımcı personeli çalıştırmalı. Bunun yükünü okula öğrencilere vermemeli. Bu bizim için çok elzem, kaliteyi çok etkiliyor. Ben temizlikle ilgilenirsem o vakti çocukların eğitiminden çalıyorum. Bunlar tabi ki kaliteyi etkiliyor. Bunların yoğrulmasıyla hepsiyle birlikte düşünürsek okul öncesi eğitimde kaliteyi oluşturan etmenlerin bir çerçevesini çizdiğimi düşünüyorum.

Kalitenin verilen eğitim ile doğru orantılı olduğunu belirtip, çocukların eğitim ortaminda mutlu olmasi, severek okula gelmesi ve ilkokula hazırlanmadaki ihtiyaçlarının karşılanması gerektiğini düşünen Ö2' nin düşünceleri ise şöyledir:

Okul öncesinde eğitimde kalite bence önce çocukların mutlu olarak eve gitmesi ve severek okula gelmesi birincisi. İkincisi ilkokula hazırlık olduğu için ilkokul bünyesine hazırlanması için çocuğun neler yapılıyor ve bunu birinci sınıfa gittiklerinde geri dönütlerden anladığımız ne, neler duyuyoruz, ona göre eğitim sistemini değiştiriyoruz kaliteyi arttırmak için çocuklara ne yapabiliriz.

Erken çocukluk eğitiminde kalitenin, öğretmenin niteliği ve fiziki ortamın niteliği ile ilgili olduğunu ifade eden AÖ1'in ifadeleri şu şekildedir:

Bunun maddelerinden bir tanesi öğretmenin eğitime bakış açısı, çok önemli. Diğeri de sınıfın mevcudu. Özellikle de sınıfın mevcudu. Okul öncesinde bu kaliteyi çok etkileyen bir şeylerden bitanesi, çocuklarla birebir ilgilenmek adına. Ve sınıfın genişliği. Yani mekan çok önemli. Çocukların rahat hareket edebildiği, oynayabildiği bir alan olması.

Yöneticilerle yapılan görüşmelerin analizleri sonucunda kalite tanımlarına ait alt temalar; "fiziki koşulların yeterli olması, sınıfın temiz olması, öğretmenin donanımlı olması, erken çocukluk eğitimi programının nitelikli olması, yardımcı personelin bulunması, eğitimin çocukların gelişim alanlarına yönelik olması, yalnızca çocuk bakımını değil eğitimini de içermesi, işini seven personelin olması, öğretmenin eğitim düzeyinin yeterli olması, çocuğun mutlu olması, çocukta meydana gelen öğrenme düzeylerinin artmış olması " olarak belirlenmiştir. Kalitenin kendileri için ne ifade ettiği sorulan yöneticilerin büyük çoğunluğunun yantlarını çocukların ihtiyaçlarını ve gelişim özelliklerini dikkate alarak verdikleri ayrıca kaliteyi verilen eğitimin kaliteli olması ile özdeşleştirerek birlikte kullandıkları görülmüştür.

Okulöncesi eğitim döneminin, eğitim kademelerinin en önemlisi olduğunu ve değerinin yeni yeni anlaşılmaya başlandığını belirtip, bu kurumlarda kalitenin oluşması için birçok etmenin bir arada bulunması gerektiğine inanan Y1 düşüncelerini şöyle aktarmıştır:

Şimdi okul öncesi eğitimde kalite dediğimiz zaman bunu birkaç başlık altında toplayabiliriz. Bu oradaki eğitimcilerin eğitim kalitesi, fiziksel koşullar, imkânlar, öğrencinin hazırbulunuşlukları da önemli. Öğrenciye eğitim hayatı boyunca öğrenim hayatı boyunca mutlu olmayı öğrenmeyi nasıl öğrenebilir onu ne ölçüde 
verebiliyoruz, çocuk öğrenmeyi ne kadar öğrenebiliyorsa oradaki kalite benim için budur.

Kalitenin verilen eğitim ortamı ile doğru orantılı olduğunu belirtip, çocukların eğitimi için gerekli ortamların oluşturulması ve hijyeninin sağlanması gerektiğini düşünen Y2'nin düşünceleri ise şöyledir:

Okul öncesi eğitimde kaliteyi tanımlayabilmem için önce şu unsurların yerine gelmesi lazım: Sınıfın fiziki koşullarının yeterli olması ve sınıfta hijyenin sağlanması, yeterli oyun alanlarının bulunması, lavaboların hijyenik olması, öğretmenlerin donanımlı olması ve bakıcı anne seçilmesi.

Erken çocukluk eğitiminde kalitenin en önemli etkenlerinin nitelikli bir erken çocukluk eğitimi programının olması ve nitelikli öğretmenlerin bulunması olarak belirten AY2 bu düşüncelerini şu şekilde ifade etmiştir:

Okul öncesi eğitimde kalite için ilk önce kaliteli bir program olması gerektiğini düşünüyorum. Bu programın yanında öğretmenlerin bilgi ve becerilerinin üst seviyede olması gerekiyor. Bir kere severek yapmaları gerekiyor. Becerikli öğretmenler ve güzel bir okul öncesi eğitimi programı, velilerin de bu konuda bilinçlendirilmesi ile kalitenin artacağını düşünüyorum.

Görüşmelerden elde edilen bulgular doğrultusunda hem öğretmenlerin, yardımcı personelin ve yöneticilerin önemle üzerinde durdukları noktanın, kaliteli eğitimin çocukların tüm gelişim alanlarını dikkate alınarak gerçekleştirilebileceği, okulöncesi eğitimin çocukların gelecekteki tüm eğitim yaşamlarının temelini oluşturacak öneme sahip olduğu, çocukların özgürce hareket ettikleri, özgürce düşünebildikleri, açıklamalar yapabildikleri, doğayı tanıyıp keşfetmeye olanak veren, sosyalleşme imkânlarının bulunduğu, yaratıcılıklarını gösterip geliştirebilecekleri ve en önemlisi kendilerini bağımsı hissedebildikleri bir eğitimin kaliteli olabileceği üzerinedir. Okul öncesi eğitim içerisinde çocukların gelişimleri için gerekli fiziksel ortamların ve materyallerin sağlanması ve bu ortamların temizliğine dikkat edilmesi de kalite ile ilişkilendirilmiştir.

Araştırmanın alt problemlerinden olan kalitenin tanımıyla ilgili yapılan görüşmelerden elde edilen bulgular, kaliteli bir eğitim için çocukların tüm gelişim alanlarının dikkate alınması gerektiğini ortaya koymaktadır. Hem öğretmenler hem yardımcı personeller hem de yöneticiler kaliteli bir okulöncesi eğitimin, sadece fiziksel anlamda iyi imkânlara sahip olmakla değil; çocukların gelecekteki tüm eğitim yaşamlarının temelini oluşturacak öneme sahip olduğu, çocukların özgürce hareket ettikleri, özgürce düşünebildikleri, açıklamalar yapabildikleri, doğayı tanıyıp keşfetmeye olanak veren, sosyalleşme imkânlarının bulunduğu, yaratıcılıklarını gösterip geliştirebilecekleri ve en önemlisi kendilerini bağımsız hissedebildikleri bir ortamla olabileceğini düşünmektedir.

\section{Anasınıflarında Görevli Öğretmenler ve Yöneticilere Göre Kaliteyi Oluşturan Öğeler Nelerdir?" Sorusuna İlişkin Bulgular}

Araştırmanın bu bölümünde "anasınıflarında ve anaokullarında görevli öğretmenler, yardımcı personel ve yöneticilere göre kaliteyi oluşturan öğeler nelerdir?" sorusuna yanıt aranmıştır. 


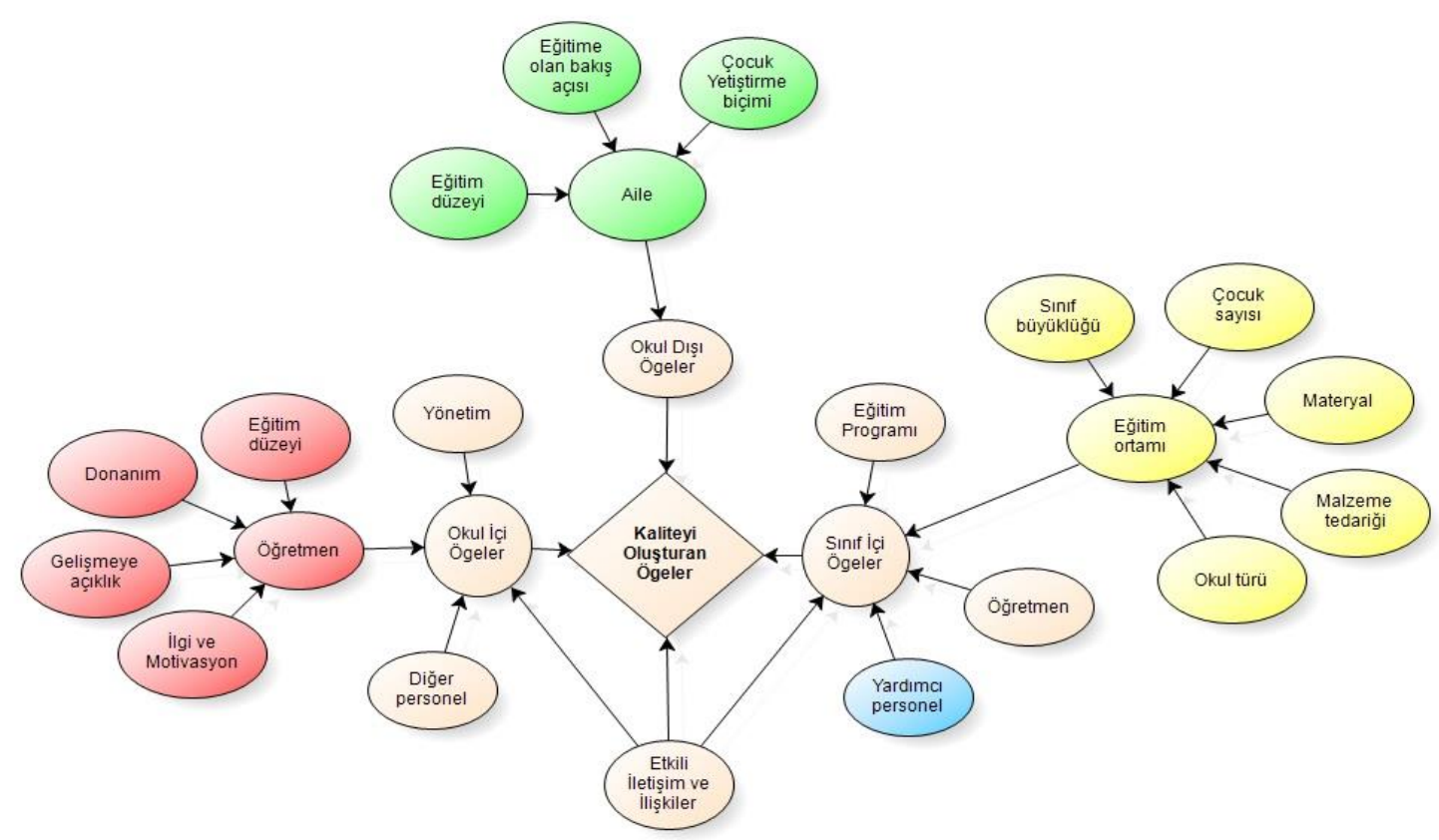

Şekil 2: Kaliteyi oluşturan ögeler

Öğretmenler ve yöneticilerle yapılan görüşmelerin analizleri sonucunda kaliteyi oluşturan öğelere ait alt temaların genel olarak "okul içi öğeler ve sınıf içi öğeler" biçiminde ikiye ayrıldığı görülmüştür. Bunlardan okul içi öğeler; "yönetim, öğretmen, diğer personel, iletişim ve ilişkiler" sınıf içi öğeler ise; "öğretmen, eğitim ortamı, eğitim programı, yardımcı personel, iletişim ve ilişkiler" olarak belirlenmiş̧tir. Kalite öğelerinin neler olabileceği sorulan öğretmenlerin tamamının bu soruya okulu bir bütün olarak düşünüp yanıt verdikleri ardından sınıf içi öğeler hakkında görüş belirttikleri görülmüş̧ür. Bu bölümde bulgular aktarılırken öncelikle okul içi öğelere ardından sınıf içi öğelere yer verilmiş daha sonra ise bu öğeler iletişim ve ilişkiler alt temalarıyla birlikte yorumlanıp aktarılmıştır.

Okulöncesi eğitimde kaliteden söz etmek için öncelikle kaliteli bir yönetimin olması gerektiğini belirtip yönetimin okulda çalışan diğer personel üzerindeki önemli etkisinin bulunduğunu aynı zamanda velilerin okul içerisindeki kalite unsuru olarak gördüğünü vurgulayan Ö3'ün görüşleri şöyledir:

Okul idaresi ile uyumlu bir şekilde çalışmak. Okul idaresi yani. Sınıftaki velilerin birbiri ile olan diyalogları da çok önemli yan bu da kaliteyi arttırıyor. Yani veli artı okul idaresi diyebilirim.

Benzer düşüncelere sahip farklı okuldan Ö2 ise bu konudaki düşüncelerini “ilk önce okul içi öğelerin başında idare geliyor tabi ki. İdare çok önemli idarenin destek olması çok önemli. Bunun yanı sıra diğer öğretmenlerin yardımı gerekiyor, özellikle branş olan okullarda; işte müzik olan, beden eğitimi öğretmeninin olması ana sınıflarına destek sağlıyor bu konuda. Sınıf ablası çok önemli; gerçekten bu işi bilen ve çocuklarla iletişiminin iyi olan birinin olması o anlamda iyi. Daha sonra da okul dışındakiler geliyor ki aile." biçiminde belirtmiştir. Ö4 ise kaliteyi oluşturan okul içi öğeler hakkındaki görüşlerini şöyle ifade etmiştir:

Bence bunun başında öğretmenin eğitim verirken bu eğitimi çocuğa iyi tanımlaması, bunu göstermesi, materyalleri en iyi şekilde kullanması gerekiyor. Başta öğretmen geliyor benim için. Bunun dışında tabii ki sınıf içerisinde kullanılan materyaller, yardımcı personelimi. Çünkü bir olay anında hemen o da etki 
edebiliyor. Çocuklar o kadar küçük oldukları için anlık olaylar çıkabiliyor. O konularda etkili olabiliyor.

Bazı öğretmenlerin ise okulun bir bütün olduğunu belirttiği ve okulda görevli temizlik ve diğer işlerden sorumlu yardımcı personellerinin bile kalitede önemli olduklarını vurguladıkları görülmüştür. Bu düşüncelere sahip Ö5'in ifadeleri şu şekildedir:

Ben yine nitelikten devam ediyorum okul içi şartlar, okulun bulunduğu çevre, yine okul içerisinde eğitimi sürdüren öğretmenin donanımı, daha önce lisans ya da varsa lisansüstü veya daha başka yerde aldıkları yüklendikleri eğitim süreçleri, kendini geliştirmek için baktığı okuduğu kitaplar ya da katıldığ1 eğitimsel süreçler veya buna bezer pek çok unsuru sayabiliriz yani. Bunlar sonucunda ortaya çıkan. Tabi bir de eğer siz bir tedbir alıyorsanız niteliği arttırmak için bunun yönetici tarafından desteklenmesi gerekiyor sadece bu da işinizi çözmüyor aynı zamanda sizden bir alt birim olarak çalışan yardımcı hizmetlinin de bunu desteklemesi lazım. Birbirini destekleyen unsurlar oldukça yapı sağlam oluyor ve eğitim de böylece yürütülüyor.

Anaokullarında görev yapan öğretmenler okul içi ve sınıf içi kalite unsurları olarak temelde personel ilişkilerini almışlardır. Okulda görevli bütün personelin birlikte hareket etmesinin önemi üzerinde durmuşlardır. Bu konudaki görüşlerini AÖ4 şu şekilde ifade etmiştir:

Aslında öğretmenlerin birbiriyle anlaşması ve paylaşım içinde olması kalite unusurlarındandır. Bence ögrretmenlerin de birbiri ile anlaşması ve hatta bütün okul içerisindeki personelin birbiri ile anlaşması önemli etmen diye düşünüyorum.

Öğretmenler kalite öğelerine ilişkin okul içi öğelerle birlikte sınıf içi öğeleri de düşünmektedirler. Genel anlamda okulu bir bütün olarak kabul eden Ö6"Okulda ne bulunur ilk başta idareciler. Okul müdürünün bakış açısı, okul içinde sınıfımızın fiziki koşulu, yardımcı personel ve öğretmene yeterli derecede materyal sağlanması. Bizim materyalimiz; yayınlarımızdır, kitaplı̆̆ımızdır, bilgisayarımızdır, cdlerimizdir, oyuncaklarımızdır. Bunlar da sağlanırsa daha iyi olur." Biçiminde bu konudaki düşüncelerini aktarmıştır.

Öğretmenlerin "kaliteyi oluşturan okul için öğeler nelerdir?" sorusuna verdikleri cevaplar incelendiğinde; kalitenin öğretmenle yakından ilişkili olduğunu belirtip bununla birlikte eğitim ortamının ve materyallerin kalite için önemli olduğunu vurguladıkları görülmektedir. Aynı zamanda öğretmenlerden bazılarının sınıf içi kalite öğelerinden öğretmen ve eğitim ortamına değindikten sonra yardımc1 personellerin varlığının da kalite adına önemli olduğunu vurguladıkları görülmektedir.

Erken çocukluk eğitiminde fiziki imkânların ve ortamların erken çocukluk eğitiminde kalite unsurları arasında önemli bir yer tuttuğu düşüncesinde olan yöneticilerden Y5'in ifadeleri şu şekildedir:

Her şeyden önemlisi fiziki durumlar, çok önemli. Maalesef bazı okullarımızda özellikle de ilköğretim bünyesinde bulunan anasınıflarında fiziki imkânlar noktasında kısıtlamalar, sınırlamalar yaşayabiliyoruz. Normal bir ilkokul ya da ortaokul öğrencisi için düzenlenen sınıfı anasınıfı şeklinde kullanılmasının gerektiği durumlar oluyor, tabi bu da ister istemez orada verilen eğitimi olumsuz yönde 
etkiliyor. Her şeyden önce fiziki imkânların bu çocukların fiziki şartlarına hatta ruhsal durumlarına da uygun olması lazım.

Y5'in "kaliteyi oluşturan okul için öğeler nelerdir?" sorusuna verdikleri cevaplar incelendiğinde yalnızca fiziksel ortamın yeterli olmadığı aynı zamanda okul ve sınıf içerisindeki diğer ilgili personel ve onların birbiri ile olan iletişim ve etkileşimleri de bu öğeler arasında yer almaktadır. Aynı fikirde olan Y4 okul ve sınıf içerisindeki bütün personelin kalitesinin bu öğeler arasına girdiğini şu şekilde ifade etmektedir:

Her şeyi fiziki şartlara bağlamamak lazım çünkü fiziki şartlar baktığın zaman dört duvardan oluşuyor, orada esas eğitimin kalitesini yansıtacak olan oradaki eğitimcinin kalitesi diyelim, hatta eğitimcinin kalitesi. Kalitenin içerisinde yöneticilerimiz de var kesinlikle şimdi bizler yöneticiler olarak onların sorunlarını, isteklerini, taleplerini anlayamayabiliyoruz. Bizim sınıf öğretmeni, branş öğretmeni olarak bizim isteklerimiz daha farklı tabi. Bunun yanında destek personel de önemli. Öğretmenin sınıfta 15-20 öğrenciye yetişmesi de mümkün değil. Bu noktada da ihtiyaç duyulan yardımcı personel işte sınıf ablası, bu arkadaşlardan destek almamız gerekiyor. Öğretmen daha çok çocuğun öğretim boyutu, eğitim boyutu ile de ilgileniyor tabi de ama burada birebir ona uygulatan sınıf ablasıdır. Çocuğun beslenme, temizlik, tuvalet gibi ihtiyaçlarında onun (sınıf ablası) yardımı gerekiyor.

Bir diğer yönetici olan Y2 ise kalite unsurlarını materyallerin zenginliği olarak düşündüğünü “Günümüzün vazgeçilmezi olan bilgisayar ve internete erişimin kolay olması, teknolojinin sınıfta kullanılması, yardımcı kitaplara sahip olmak." Şeklinde olan ifadelerinden anlamak mümkündür. Personel noktasında bu unsurların oluştuğunu düşünen $\mathrm{Y}^{\prime}$ 'ün ifadeleri ise şu şekildedir:

İdare önemli bölüm, sonra öğretmen daha sonra veli ve sınıftaki bakıc1 ablamız bence önemli birleşenler. Bir araya getirdiğimizde önemli bileşenler.

Anaokulunda görev yapan yöneticilerden AY3 kalitenin okul içi unsurları hakkındaki düşüncelerini şu şeklide aktarmıştır:

Yani aklımıza ilk fiziksel ortam geliyor. Bir başka unsur öğretmen, çok belirleyici. Bir başkası eğitim programı, ne yapıyor olduğumuz ve onun nasıl uygulandığı öğretmen tarafından. Ve okulda çocukla temas eden diğer yetişkinler.

Öğretmenler ve yöneticilerle yapılan görüşmelerin analizleri sonucu; kaliteyi oluşturan öğelerin genel anlamda okul içi ve sınıf içi olarak ikiye ayrıldı̆̆ görülürken, bu iki alt temanın temelinde ise okul içi-sınıf içi iletişim ve ilişkilerin olduğu anlaşılmıştır. Bu noktada öğretmenlerin ve yöneticilerin yapılan görüşmelerden elde edilen bulgular birlikte karşılaştırmalı olarak verilmiştir.

Öğretmenler ve yöneticileri okul içi kalite öğelerinin en önemli unsuru olarak gördüklerini yönetimde bulunan kişilerin aslında okulda gerçekleştirilen tüm aktivite ve uygulamaları biçimlendirdiğini belirtmişlerdir. Bu noktada yöneticiler ile yapılan görüşmelerde ise yöneticilerin, kalite unsuru içerisinde öğretmenlerin önemli yer kapladıklarını belirttikleri görülmektedir.

Öğretmenlerin ve yöneticilerin verdikleri cevaplar incelendiğinde; her iki paydaşın kaliteyi oluşturan öğeler için üzerinde önemle durdukları noktanın, okulöncesi eğitim kurumlarının bir bütün olarak yöneticisinden yardımcısına, temizlik personelinden eğitim ortamına kadar her şeyin bir bütün olarak algılanması gerektiği düşüncesidir. Aynı zamanda katılımcılar kaliteyi oluşturan öğelerin 
temelinde sağlıklı iletişime dayalı kurulan ilişkilerin var olduğunu vurgulamışlardır. İletişim ne kadar sağlıklı ve sürekli ise ilişkiler de o denli kuvvetli ve samimi olmaktadır. Nitelikli ilişkiler kurum içi birlikteliğin ve ekip ruhunun oluşumunu desteklemektedir. Ekip ruhuyla gelen bu huzurlu çalışma ortamı ise sınıfa yansıdığı için çocuklara verilen eğitim kaliteli ve verimli hale gelmektedir. Aksi durumların ise ilişkileri ve sınıf ortamını olumsuz etkilediği katılımcılar tarafından belirtilmiştir. Bununla birlikte kalite unsurları içerisinde fiziksel ortamların ve materyallerin de önemli bir yer kapladığı öğretmenler ve yöneticiler tarafından ifade edilmiştir.

Araştırmanın sonuçlarından olan "kaliteyi oluşturan öğelere" ilişkin bulgulara bakıldığında, öğretenlerin ve yöneticilerin verdikleri cevaplar doğrultusunda kaliteyi oluşturan öğeler okul içi öğeler ve sınıf içi öğeler olmak üzere iki alt temaya ayrılmıştır. Okul içi öğeler; "yönetim, öğretmen, diğer personel, iletişim ve ilişkiler" sınıf içi öğeler ise; "öğretmen, eğitim ortamı, yardımcı personel, iletişim ve ilişkiler" olarak belirlenmiştir. Hem öğretmenlerin hem de yöneticilerin kaliteyi oluşturan öğeler için önemle üzerinde durdukları nokta, okulöncesi eğitim kurumlarının bir bütün olarak yöneticisinden yardımcısına, temizlik personelinden eğitim ortamına kadar her şeyin bir bütün olarak algılanması gerektiği düşüncesidir. Aynı zamanda katılımcılar kaliteyi oluşturan öğelerin temelinde sağlıklı iletişime dayalı kurulan ilişkilerin var olduğunu vurgulamışlardır. İletişim bütün personelin sağlıklı bir şekilde çalışmasını sağlayacak temel faktörlerdendir. Ekip ruhuyla gelen bu huzurlu çalışma ortamı ise sınıfa yansıdığı için çocuklara verilen eğitim kaliteli ve verimli hale gelmektedir. Aksi durumların ise ilişkileri ve sınıf ortamını olumsuz etkilediği katılımcılar tarafından belirtilmiştir.

\section{Anasınıflarında ve anaokullarında Görevli Öğretmenlere ve Yöneticilere Göre Yardımcı Personeller (Sınıf Annesi/Ablası) Kimdir? Sorusuna İlişkin Bulgular}

Bu bölümde "anasınıflarında ve anaokullarında görevli öğretmenlere ve yöneticilere göre yardımcı personeller (sınıf annesi/ablası) kimdir? Sorusuna yanıt aranmıştır.

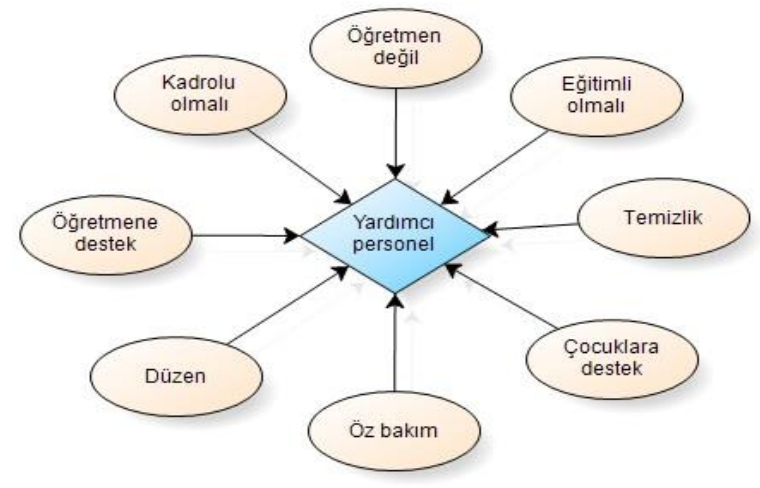

Şekil 3: Yardımc1 personel (sınıf ablası/annesi)

Öğretmenlerle ve yöneticilerle yapılan görüşmelerin analizleri sonucunda yardımcı personel tanımlarına ait alt temalar "temizlik ve düzen, etkinliklere destek, öz bakım, çocuklara destek, öğretmen değil" olarak belirlenmiştir.

Yardımcı personellerin kendileri için ne ifade ettiği sorulan öğretmenlerin büyük kısmı özellikle öz bakım becerileri ile temizlik ve düzen konularına değinmiştir. Sınıf annesi/ablası/yardımcılarının, öğretmenlere özellikle temizlik ve 
düzen anlamında yardımcı olduğunu belirten bazen de sınıfta olmadığı zamanlarda öğretmenin yerini aldığını söyleyen öğretmenlerden Ö2'nin görüşleri şöyledir:

Sınıf ablasının yeri çok önemli çünkü öğretmeni tamamlayan bir unsur aslında sınıf ablası. Gerçekten o pozisyonda eğitimi belli bir seviyede ise, çocuklara yaklaşımı iyi ise tamamen öğretmene destek, sanki yardımcı personel statüsüne giriyor. O anlamda destek modülü çok fazla yani çocuklara birtakım kavramları öğretmede yardımcı oluyor destekliyor öğretmeni, öğretmenin anlattıklarını tekrarlatıyor; işte tuvalet eğitimi en başta, soyunma giyinme her ne kadar öğretmen yapsa da belli bi şeyden sonra sınıf ablası ya da annesi kimse o ilgileniyor.

Benzer şekilde yardımcı personel çocukların öz bakım ihtiyaçlarının karşılanması noktasında ön plana çıktığını ve öğretmenlere etkinliklerde destek sağladığını düşünen Ö5 bunu “Genelde böyle öz bakım becerilerinde ön plana geçiyor. Benim hazırladığım eğitimsel süreçlerin dağıtımını üstlenebiliyor. Ya da herhangi bir şekilde böyle yetişemediğim durumlar olabiliyor yani daha hılı ilerlemesi için ufak tefek yine boyaların dağıtılmasıdır masaların silinmesidir o şekilde yani." Şeklinde ifade etmiştir.

Yardımcı personelin, öğretmenlere özellikle temizlik ve düzen anlamında yardımcı olduğunu belirten bazen de sınıfta olmadığı zamanlarda öğretmenin yerini aldığını söyleyen öğretmenlerden Ö4'ün görüşleri şöyledir:

Öğretmen biraz daha eğitimde kuralı oluşturuyor. Ama sınıf annesi \ablası çocuklara daha çok sevgi anlamında ya da çocukların sağlı̆̆ı açısından, tuvalet kültürü, temizliği açısından yardımcı oluyor. Artı öğretmenin yetişemediği konularda direk gözlemleyip yardımcı olabiliyor.

Benzer düşüncelere sahip farklı kurumda görevli öğretmenlerden Ö1 ise görüşlerini "Sınıf içerisinde sanat etkinliği yaparken, bir hikaye okurken, bir oyun oynarken çocuğumun tuvalet ihtiyacı için sınıfımı bırakırsam, yemek zamanında masayı temizlerken sınıfımı bırakırsam bunlar benim kalitemi düşürecektir aynı zamanda tehlike de arz edecektir sınıfın içerisinde. $O$ yüzden milli eğitim bize kadrolu bir çalışan temin etmeli." şeklinde aktarırken öğretmenlerden Ö3'ün yardımcı personellerin öğretmen olmadığını vurguladığı görüşünü şöyle ifade etmiştir:

Her sınıfta 1 sınıf ablası olmalı. Vazgeçilmezin vazgeçilmezi bu. Kaliteyi nasıl etkiler, öğretmen açısından daha büyük bir rahatlık yani öğretmen nedir, çocuğu işte tuvalete götürecek el yıkatacak yani bunlar olmayacak bakıcı ablanın görevi olacak, öğretmenin görevi sadece çocuklarla ilgilenmek ama bu ablanın da çok bilinçli bir abla olması gerekiyor.

Anaokulunda görev yapmakta olan öğretmenlerden AÖ3 yardımc1 personellerin kim olduğu konusundaki düşüncelini şu şeklide ifade etmiştir:

Şimdi mesela bizim çocuklar tuvalete gittikleri zaman bizim yardımcı personelimiz ilgileniyor onunla. Sınıfın temizlenmesi durumunda gerekli temizliği yapıyor. Yaptı̆̆ımız etkinlikler sonrası sınıfımız, yerler kirleniyor, bu çok normal, burada yardımcı personelimiz temizliğini yapıyor.

Yöneticiler ile yapılan görüşmelerde "kaliteyi oluşturan okul içi öğeler arasında yardımcı personelin yeri nedir?" sorusuna verdikleri yanitlar incelendiğinde "öğretmene destek hizmet sunan" teması ön plana çıkmaktadır. 
Yöneticilerden bu konuda düşüncelerini aktaran Y1 bu durumu şu şekilde ifade etmektedir:

Okul içi öğeler bir bütün. Birini birinden ayırmak pek mümkün değil. Ekip halinde yapılması gereken bir şey. Sınıf ablası genelde destek hizmet sunan yardımcı. Burada kalite anlamında sıkıntılar yaşanabiliyor. Burada meslek lisesi çocuk gelişimi bölümü veya ön lisans mezunlarını almak tercih sebebi fakat bu kişileri burada böyle kısa süreli çalıştırmak 4 ay ilk dönem 4 ay ikinci dönem toplam 8 ay çalıştırmak ve arada ekonomik anlamda kesintiler olmasından dolayı daha çok onlar özel sektöre yöneliyorlar. Nitelikli eleman bulmada sıkıntı yaşanıyor.

Bir diğer yönetici olan Y2 ise, "Sınıf ablası öğrencilere eğitim vermez, ihtiyaçların karşılanmasına yardımcı olur." Şeklinde ifadede bulunmuştur. Yardımcı personellerin önemli bir bileşen olduğunu belirten Y3 “önemli bir yere sahip. Çünkü çocuğu emanet ediyorsunuz, öğretmenden sonra çocuğun emanet edildiği bir kişi. Dolayısıyla bu kişinin her şeyiyle, her haliyle eğitimli olması gerekiyor; görüntüsünden tutunda, konuşması, davranışları, çocuklara hitabet şekli ya da olayların çözümünde yer alacaksa, olayları çözüş şekli bile çok önemli" ifadelerini kullanmıştır. Anaokulunda görev yapan AY2 ise yardımcı personelin yeri hakkındaki düşüncelerini şu şekilde ifade etmiştir:

Şimdi yardımcı personel, öğretmen sınıfta etkinlik yaparken işte sınıfın ayarlanması düzenlenmesi ya da belki bir materyal hazırlamasında yardımcı olabilir öğretmenimize. Özbakım becerilerinde yardımcı personelimiz rehberlik ediyor. İşte lavaboya gitmede falan. Ya da işte üzerinin değiştirilmesi gerektiğinde yardımcı personelden destek alıyoruz.

Görüşmelerden elde edilen bulgular doğrultusunda öğretmenlerin ve yöneticilerin yardımcı personeller hakkındaki görüşlerinde hem fikir oldukları, birbirini destekler düşünceleri paylaştıkları görülmüştür. Bu noktada öğretmenlerin önemle üzerinde durdukları konuların, çocukların sağlıkları için yardımcıların titiz, temiz ve düzenli olmaları gerektiği, etkinliklere öğretmen direktifleriyle destek vermeleri gerektiği, sınıfların kalabalık olmasından kaynaklı yardımcılara ihtiyaç duyulduğu ve yardımcıların alımında kriterlerin göz önüne alınması gerektiği düşüncesidir. Aynı zamanda katılımcıların birçoğu Türkçeyi doğru konuşabilen, sabırlı, anlayışlı, hoşgörülü, titiz işbirliği yapabilen, adil ve yaşanan sorunlara pratik çözüm yolları üretebilen yardımcıların eğitime kalite anlamında değer kazandıracağı görüşündedir.

Araştırmanın bir diğer amacı doğrultusunda yardımcı personellerin kaliteye etkisini incelemek olduğundan, yardımcı personellere ilişkin bulgularda; öğretmenlerin ve yöneticilerin verdikleri cevapların birleştiği noktalar olarak; yardımcı personellerin gerçek öğretmen olmadığı; temizlik ve düzenden sorumlu, etkinliklere destek veren ve çocukların öz bakımlarına hizmetlerine destek sağlayan kişiler olduğu sonucuna ulaşılmıştır.

\section{Tartışma, Sonuç ve Öneriler}

Okul öncesi dönemde kaliteyi açıklamaya yönelik yapılan araştırmalar farklı tanımlamalar ortaya koysa da genellikle kalitenin yapısal ve işlevsel kalitenin etkileşimi ve birleşimi ile gerçekleştiğini söylemektedir (Canbeldek ve Erdoğan, 2017; Morabito, Van de gaer, Figueroa ve Vandenbroeck, 2018; Zembat, 2007). Okul öncesi dönemde kalitenin bileşenlerinden, yapısal kalitenin unsurları olarak sınıf 
büyüklüğü, öğretmen - çocuk oranı, öğretmenin eğitim düzeyi ve hizmet yılı olarak söylenebilir. İşlevsel kalite birleşenlerinde ise, çocukların onlara bakım veren yetişkinlerle etkileşimleri ve öğrenmeyi arttıran materyal ve faaliyetlerle etkileşimde bulunma yer almaktadır (Canbeldek ve Erdoğan, 2017).

Kaliteli bir kurum sadece fiziksel olarak yeterlilikle sınırlı değildir. Fiziksel yeterlilikler sadece kaliteyi oluşturan bir öğedir. Daha önce yapılan araştırmalar da kaliteyi sadece fiziksel mekân ve materyallerle sınırlandırmamaktadır. Kaliteli bir eğitim fiziksel çevre ve materyallerin yanı sıra, öğretmen yeterlilikleri, sınıftaki çocuk sayısı, öğretmen başına düşen çocuk sayısı, öğretmen ve çocuk etkileşimleri, uygulanan program, iletişim ve aile eğitimi ve katılımı gibi faktörlerden etkilenmektedir (Karademir ve Ören, 2020). Bu bağlamda, öğretmenler ve yöneticiler kalite kavramını literatürde yer alana benzer şekliyle açıklamıştır.

Sevinç (2006) yaptığı araştırmada annelerin çocuğun gelişimine önem verdikleri, okul seçiminde belli standartlara dikkat ettikleri ve eğitim ortamının sağlıklı ve güvenilir olmasını istedikleri sonucuna ulaşmıştır. Yapılan bu araştırmada annelerin okul seçiminde güvenilir olmasını personel noktasında da istemektedirler. Okulun fiziksel çevresinin güven oluşturmasının yanında çocuğun eğitiminde yer alan personellerin de güven düzeylerinin yüksek olmasını beklemektedirler. Bu araştırmadan hareketle erken çocukluk eğitimindeki personel kalitesinin ön plana çıkmaktadır.

Balyer (2013) yaptı̆̆ı araştırmada okul müdürlerinin öğretmenlerle yapıcı bir diyalog kurduğu, öğretmenlere geri dönüt verdiği ve öğretmenlerin yaptığ1 iyi işleri takdir ettiği sonucuna ulaşmıştır. Ayrıca müdürlerin iyi bir model olmaya çalıştığı, öğretmenler arasında işbirliğini teşvik ettiği ve öğretimin kalitesine vurgu yaptığ sonucuna ulaşmıştır. Dolayısıyla müdürlerin bu faaliyetleriyle okuldaki kaliteyi yükseltmede önemli bir faktör olduğu ifade edilmiştir. Susmak ve Hacıfazlıoğlu (2013) tarafından yapılan araştırmada ise erken çocukluk eğitim kurumu yöneticilerinde bulunması gereken nitelikleri takım çalışmasına yatkın olma ve insana değer verme olarak bulmuşlardır. Ayrıca yöneticilerin tutarlı ve destekleyici olmaları gerektiği ifade edilmiştir.

Okulöncesi eğitim kurumlarında, kalite birçok öğeden oluşan ve birbirinden bağımsız olmayan bir ilişkiye dayanmaktadır. Nasıl ki tek başına fiziksel mekânın ve kullanılan materyalin kalitesi bir okulu kaliteli hale getirmek için yeterli değilse, tek başına öğretmenin ya da programın kalitesi de yeterli değildir. Kaliteyi oluşturan bütün öğelerin birbiriyle etkileşim içinde olup, uyum içerinde çalışması kalitenin başlaması ve devamı açısından oldukça önemlidir. Alanyazında, kaliteyi oluşturan unsurlar genelde iki kategori altında toplanmaktadır: a) yapısal kalite b) sürecin kalitesi (Epinosa, 2002; Zigler, Gilliam ve Jones, 2006). Sınıftaki öğrenci sayısı, öğretmen başına düşen öğrenci sayısı ve öğretmenlerin ve idarecilerin eğitimi yapısal kaliteyi oluştururken; etkileşimler, etkinlikler, materyaller, sağlık ve güvenlik gibi unsurlar da sürecin kalitesini oluşturmaktadır (Epinosa, 2002). Öğretmenler ve yardımcı öğretmenler, alanyazında belirtilen kalitenin çoğu unsuruna değinmiştir. Fakat oldukça önemli iki nokta olan sınıftaki öğrenci sayısı ve öğretmen başına düşen öğrenci sayısı göz ardı edilmiştir. Bununla birlikte öğretmenlerin ve yardımcı öğretmenlerin çocuklarla iletişiminin önemi hakkındaki bulgular alanyazınla tutarlıdır. Shonkoff ve Philips (2000), yaptıkları araştırmada çocukların, 
öğretmenlerinden ve akranlarından aldıkları teşviklerle en iyi şekilde öğrendiklerini ortaya koymuşlardır.

Araştırmada yardımcı personellerin, sadece sınıflarda öğretmene yardımcı olan personeller değil, çoğu zaman çocuklarla daha fazla zaman geçiren, onlarla birebir ilgilenen kişiler olduğu sonucuna varılmıştır. $\mathrm{Bu}$ nedenle, yardımcı personeller istihdam edilirken çocuklarla iletişimi güçlü, çocukları seven, çocuk gelişimi konusunda bilgili ve insanlarla uyum içerisinde çalışabilecek kişiler tercih edilmelidir. Yardımcı personellerin öğretmenlerle koordineli bir şekilde çalışması, iyi bir öğrenme ortamı oluşmasına bu da doğal olarak başarılı çocuklar yetişmesine olanak sağlamaktadır. Araştırmanın bu bulgusu Karademir ve arkadaşlarının (2017) yaptığı araştırmanın bulgularıyla benzerlik gösterirken bu konuda Shim, Hestenes, ve Cassidy (2004)'nin yaptıkları çalışmada, öğretmenin ve yardımcı personelin koordineli bir şekilde çalıştığı sınıflardaki kalite, hem aralarında hiyerarşik bir ilişki olan iki öğretmenli sınıflara hem de tek öğretmenli sınıflara göre daha yüksek çıkmıştır. Ancak bazı araştırmaların ise bu görüşü farklı bir açıdan ele aldığı anlaşılmaktadır. Yardımcı öğretmenlerin (alan eğitimi olmayan), eğitim etkinliklerine çok fazla müdahalede bulunmadan, çocukların bakım ve ihtiyaçlarıyla birebir ilgilenmesi ve öğretmenlerle aralarındaki hiyerarşik seviyeyi koruması öğretmenler açısından görülmektedir. Aynı şekilde yöneticilerin bazıları yardımcı personeller için; çocuklarla ve öğretmenle ilişki kurmanın önemli olduğunu ama belli sinırlar içerisinde bunun gerçekleşmesi gerektiğini belirtmiştir. Yapılan bir çalışma öğretmenlerin bu düşüncesini destekler niteliktedir. Sosinky ve Gilliam (2011) yaptıkları çalışmada, öğretmenler yardımcı öğretmenler hakkında, eğitim faaliyetlerinde daha az kullanışlı olduğunu, fakat sınıfın düzenlenmesi ve çocukların denetlenmesinde ise oldukça yararlı olduğunu düşünmektedir.

Arlington Public Schools (2005) tarafından yapılan bir araştırmada öğretmenler, yardımcı personellere en çok sınıftaki çocukların güvenliği için ihtiyaç olduğunu belirtmiştir. O yaşlardaki çocukların tek başlarına sınıf dişına çıkamayacakları için ve öğretmenin sınıf dışına çıkması gerektiği durumlarda da sınıf içerisinde güvenliğin sağlanması konusunda yardımcı personellere büyük iş düşmektedir. Bir başka öğretmenin de, daha az sayıda çocukla tek başına çalışmaktansa, daha fazla çocukla ve yardımcı personelle çalışmayı tercih ettiği görülmektedir.

Kalite sadece kurumun fiziki alt yapısı ile ilişkili olmayıp, sınıf ortamında eğitim-öğretime dahil olan tüm personelleri ve zengin öğrenme çevresini ilgilendiren bir olgudur. Kaliteyi oluşturan unsurlardan personel kısmında, sınıf içerisindeki yardımcı personellerin etkili olduğunu görmekteyiz. Ancak erken çocukluk eğitiminin yapıldığı kurumlarda yardımcı personel çalıştırmak okul yönetiminin, öğretmenlerin ve velilerin isteğine bırakılarak sınıflarda bulundurulan personelin sosyal güvence ve maaş giderleri veliler tarafından karşılanmaktadır. Bu durum önemi bilinen ancak değeri bilinmeyen bir kitleyi işaret etmektedir. Erken çocukluk eğitimi hizmetlerinin gerçekleştirilmesinde tüm sınıflarda yardımcı personel (öğretmen, abla, anne) bulundurulması niteliğin artırılması ve çocuklarımızın daha etkin öğrenmeler gerçekleştirebilmesi adına önemlidir. MEB tarafından zorunlu hale getirilip böyle bir meslek kolunun oluşturulması sağlanmalı ve eğitimde eşitlik ilkesinin yürütülmesi göz önüne alınmalıdır. Böyle bir iş kolunun oluşturulması 
özellikle kız meslek liselerinin çocuk gelişimi bölümünden mezun olan adaylar için sosyal güvence ve devamlı bir maaş anlamında cazip hale getirilebilir.

\section{Kaynakça}

Anne Çocuk Eğitim Vakf1 [AÇEV]. (2009). Türkiye'de erken çocukluk eğitimi: Erişim, eşitlik ve kalite. İstanbul: AÇEV Yayınları.

Ağgül Yalçın, F. ve Yalçın, M. (2018). Okul öncesi öğretmenlerin okul öncesi eğitimin sorunlarıyla ilgili görüşleri: A ğrı ili örneği. İlköğretim Online, 17(1), 367-383. doi: 10.17051/ilkonline.2018.413784.

Arlington Public Schools. (2005). Budget study on kindergarten assistants. department of finance and management services department of instruction. Arlington, VA.

Aydagül, B. (2009). Türkiye'de erken çocukluk eğitimi: Erişim, eşitlik ve kalite. Early childhood education in Turkey: Accessibility, equality, and quality. İstanbul: The Mother Child Education Foundation.

Balyer, A. (2013). Okul müdürlerinin öğretimin kalitesi üzerindeki etkileri. Kuram ve Uygulamada Ĕ̈itim Yönetimi, 19(2), 181-214.

Baştürk, R. ve Işıkoğlu, N. (2008). Okul öncesi eğitim kurumlarının işlevsel kalitelerinin çok yüzeyli Rasch ölçme modeli ile analizi. Kuram ve Uygulamada Ĕgitim Bilimleri / Educational Sciences: Theory E Practice.8(1). 7-32.

Bekman, S. ve Gürlesel, C.F. (2005). Doğru Başlangıç: Türkiye'de Okulöncesi Eğitim. İstanbul: TÜSİAD Yayını

Biehl, K. (2011). Türkiye'de Okul Öncesi Eğitimde Kalite Standartları Durum Analiz Raporu. Okul Öncesi Eğitimi Güçlendirme Projesi.

Bowman, B.T., Donovan, M.S., and Burns, M.S. (Ed.). (2001). Eager To Learn: Educating Our Preschoolers. Washington, DC: National Academic Press.

Bryant, D. M., Burchinal, M., Lau, L. B., and Sparling, J. J. (1994). Family and classroom correlates of Head Start children's developmental outcomes. Early Childhood Research Quarterly, 9, 289-309.

Burchinal, M. R., Cryer, D., Clifford, R. M., and Howes, C. (2002). Caregiver training and classroom quality in child care centers. Applied Developmental Science, 6(1), 2-11. https://doi.org/10.1207/S1532480XADS0601_01

Büyüköztürk, Ş., Kılıç Çakmak, E., Akgün, Ö. E., Karadeniz, Ş. ve Demirel, F. (2013). Bilimsel Araştırma Yöntemleri (15. Baskı). Ankara: Pegem Akademi Yayıncılık.

Can ve Kılıç (2019). Okul öncesi eğitim: temel sorunlar ve çözüm önerileri. Milli Eğitim Dergisi, 48 (1), 483-519.

Canbeldek, M. ve Erdogan, N. I. (2017). The effects of early childhood classroom size and duration on development of children. Eurasian Journal of Educational Research, 68, 257-271, http://dx.doi.org/10.14689/ejer.2017.68.14

Demircan Aydın, Z. (2017). Öğretmen ve yöneticilerin okul öncesi eğitimi değerlendirmeleri ve bu alanda yaşanan yönetimsel sorunlar. (Yayımlanmamış Yüksek Lisans Tezi). Okan Üniversitesi, Sosyal Bilimler Enstitüsü.

Dilek, H. ve Duman, T., (2014). 2006 okul öncesi eğitim programının değerlendirilmesi.

Dünya Bankası İnsani Kalkınma Departmanı [DBİKD], (2011). Türkiye de temel eğitimde kalite ve eşitliğin geliştirilmesi. Zorluklar ve Seçenekler. Rapor No: 54131-TR. 
Early, D. M., and Winton, P. J. (2001). Preparing the workforce: Early childhood teacher preparation at 2- and 4-year institutions of higher education. Early Childhood Research Quarterly,16, 285-306. https://doi.org/10.1016/S08852006(01)00106-5

Eğitim Reformu Girişimi [ERG] (2008). Eğitim izleme raporu 2008. İstanbul: ERG Epinosa, L.M. (2002). High-quality preschool: Why we need it and what it looks like. Preschool Policy Matters, 1. National Institute For Early Education Reseach.

Ertör, E. ve Durdağı, A. (2016). Anasınıfı öğretmenlerinin personel hizmetleri ve genel hizmetlerde yaşadıkları sorunlara ilişkin öğretmen görüşleri. Bayburt Ĕ̆itim Fakültesi Dergisi, 11(1), 1-21.

Gökmen, D., (2010). Okul Öncesi Eğitim Süreci İç Denetim Raporu. Milli Eğitim Bakanlığ 1 İç Denetim Birimi Başkanlığı.

Güleş, F., ve Erişen, Y. (2013). Okul öncesi eğitimde fiziksel çevre standartlarını belirleme: paydaş görüşlerine dayalı bir analiz. Selçuk Üniversitesi Sosyal Bilimler Enstitüsü Dergisi, (30), 129-138.

Gür, B. S. ve Çelik, Z. (2009). Türkiye'de Millî Ĕ̆itim sistemi: Yapısal sorunlar ve öneriler. Ankara: SETA.

Hayes, C. D., Palmer, J. L., and Zaslow, M. J. (Ed). (1990). Who cares for America's children?. National Academies Press.

Hu, B. Y., and Szente, J. (2009). Exploring the quality of early childhood education in China: Implications for early childhood teacher education. Journal of Early Childhood Teacher Education, 30(3), 247-262. https:/ / doi.org/10.1080/10901020903084330

International Step by Step Association, (2010a). Competent Educators of the 21st Century Principles Of Quality Pedagogy.

International Step by Step Association, (2010b). Study on the Implementation of the ISSA Pedagogical Standards and Their Impact on ECDE Policies and Practices in the Region of ISSA's Network and Beyond (2001-2008). Executive Summary.

Jalongo, M. R., Fennimore, B. S., Pattnaik, J., Laverick, D. M., Brewster, J., and Mutuku, M. (2004). Blended perspectives: A global vision for high-quality early childhood education. Early Childhood Education Journal, 32(3), 143-155. https:/ / doi.org/10.1023/B:ECEJ.0000048966.13626.be

Karademir, A. ve Ören, M. (2020). Okul iklimi: Anaokulu yöneticileri ve öğretmenlerin bakış açısıyla karşılaştırmalı bir araştırma. Eğitimde Nitel Araştırmalar Dergisi - Journal of Qualitative Research in Education, 8(1), 206-236. doi:10.14689/issn.2148-2624.1.8c.1s.10m

Karademir, A., Cingi, M. A., Dereli, F. ve Akman, B. (2017). Quality in preschool education: The views of teachers and assistant teachers. Bayburt Eğitim Fakültesi Dergisi, 12(23), 7-33. https:/ / doi.org/10.14689/issn.2148-2624.1.8c.1s.10m

Kerem, E. A., ve Cömert, D. (2005). Türkiye' de okul öncesi eğitimin sorunları ve çözüm önerileri. Eğitim Araştırmaları, 21, 155-172.

Kildan, A. O. (2010). Okul öncesi eğitim bağlamında; "Eğitim hizmetlerinde kalite". Suleyman Demirel University Journal of Faculty of Economics $\mathcal{E}$ Administrative Sciences, 15(2).

Köksal, O., Balaban Dağal, A. ve Duman, A. (2016). Okul öncesi öğretmenlerinin okul öncesi eğitim programı hakkındaki görüşlerinin belirlenmesi. The Journal of 
Akademic Social Science Studies, (46), 379-394.

https://doi.org/10.9761/JASSS3395

Leob, S., Fuller, B., Kagan, S.L., and Carrol, B. (2004). Child care in poor communities: Early learning effects of type, quality and stability. Child Development, (75) (1), 47-65. https:/ / doi.org/10.1111/j.1467-8624.2004.00653.x

LoCasale-Crouch, J., Konold, T., Pianta, R., Howes, C., Burchinal, M., Bryant, D., and Barbarin, O. (2007). Observed classroom quality profiles in state-funded prekindergarten programs and associations with teacher, program, and classroom characteristics. Early Childhood Research Quarterly, 22(1), 3-17. https:// doi.org/10.1016/j.ecresq.2006.05.001

Logan, H., Press, F., and Sumsion, J. (2012). The quality imperative: Tracing the rise of'quality'in Australian early childhood education and care policy. https:/ / doi.org/10.1177/183693911203700302

Micozkadığlu, İ. İ. ve Kazak Berument, S. (2003). Okul öncesi kurumların kalitesi ve çocukların sosyal yeterliği. Türk Psikoloji Dergisi, 18(51), 78-93.

Millî Eğitim Bakanlı̆̆1 [MEB]. (2018). Güçlü yarınlar için 2023 eğitim vizyonu belgesi. http://2023vizyonu.meb.gov.tr/doc/2023_EGITIM_VIZYONU.pdf, web adresinden 15 Eylül 2019 tarihinde edinilmiştir.

Morabito, C., Van de gaer, D., Figueroa, J. L., and Vandenbroeck, M. (2018). Effects of high versus low-quality preschool education: A longitudinal study in Mauritius. Economics of Education Review, 65, 126 - 137. https:/ / doi.org/10.1016/j.econedurev.2018.06.006

On Birinci Kalkınma Planı (2019-2023).Resmî Gazete (Sayı: 30840(Mükerrer)). https:/ / www.resmigazete.gov.tr/eskiler/2019/07/20190723M1-1-1.pdf, web adresinden 26 Ağustos 2019 tarihinde erişilmiştir.

Patton, M. Q. (2014). Nitel araştırma ve değerlendirme yöntemleri. Ankara: Pegem Akademi.

Sevinç, M. (2006). Okul öncesi eğitimi alan çocukların annelerinin okuldan beklentileri. Atatürk Üniversitesi Kazım Karabekir Eğitim Fakültesi Dergisi, (13).

Shim, J., Hestenes, L., and Cassidy, D. (2004). Teacher structure and child care quality in preschool classrooms. Journal of Research in Childhood Education,19 (2), 143-157. https://doi.org/10.1080/02568540409595061

Shonkoff, J. P., and Phillips, D. A. (Eds.). (2000). From neurons to neighborhoods: The science of early childhood development. Washington, DC: National Academy Press.

Sildir, E., ve Akın, U. (2017). Okul öncesi eğitime ilişkin okul müdürlerinin görüşlerinin incelenmesi. Amasya Üniversitesi Eğitim Fakültesi Dergisi, 6(1), 134165.

Sosinsky, L. S., and Gilliam, W. S. (2011). Assistant teachers in prekindergarten programs: What roles do lead teachers feel assistants play in classroom management and teaching? Early Education And Development, 22(4), 676-706. https:/ / doi.org/10.1080/10409289.2010.497432

Susmak, M., ve Hacıfazlığlu, Ö. (2013). Öğretmenlerin görüşlerine göre okul öncesi eğitim kurumlarında görev yapan yöneticilerin sahip olması gereken özellikler. Journal of Social Sciences/Sosyal Bilimler Dergisi, 6(13).

https:/ / doi.org/10.14520/adyusbd.436 
Şimşek, Z. C. ve İvrendi, A. (2014). Ebeveynlerin Okul Öncesi Eğitim Kurumlarından Beklentileri. Hacettepe Üniversitesi Ĕ̆itim Fakültesi Dergisi,29(29-2).

Taguma, M., Litjens, I., and Makowiecki, K. (2012). Quality Matters in Early Childhood Education and Care: Finland. OECD Publishing. 2, rue Andre Pascal, F-75775

Paris Cedex 16, France. https:/ / doi.org/10.1787/9789264173569-en

The World Bank, (2013). Expanding and improving early childhood education in Turkey. Rapor No: 77723-TR

Tükel, A. (2017). 2013 Okul öncesi eğitim programı ile ilgili öğretmen görüşleri.

(Yayımlanmamış Yüksek Lisans Tezi). Selçuk Üniversitesi, Eğitim Bilimleri Enstitüsü.

Türk Eğitim Derneği [TED]. (2007). Türkiye'de okul öncesi eğitim ve ilköğretim sistemi temel sorunlar ve çözüm önerileri. Ankara: Türk Eğitim Derneği.

Türk Sanayicileri ve İş Adamları Derneği [TÜSİAD]. (2005). Doğru başlangıç: Türkiye'de okul öncesi eğitim. İstanbul: TÜSİAD Yayını.

Wertfein, M., Spies-Kofler, A., and Becker-Stoll, F. (2009). Quality curriculum for under-threes: the impact of structural standards. Early Years, 29(1), 19-31. https:/ / doi.org/10.1080/09575140802685297

Whitebook, M. (2003). Bachelor's degrees are best: Higher qualifications for prekindergarten teachers lead to better learning environments for children. Washington, DC: The Trust for Early Education.

Yildirim, A. ve Şimsek, H. (2012). Sosyal bilimlerde nitel arastirma yontemleri. Ankara: Seçkin.

Zan, B. (2005). NAEYC accreditation and high quality preschool curriculum. Early Education and Development, 16(1), 85-104. https:/ / doi.org/10.1207/s15566935eed1601_6

Zembat, R. (2007). Okul öncesi eğitimde nitelik. Oktay, A. ve Polat Unutkan, O. (Ed.), Okul öncesi eğitimde güncel konular icinde (ss. 25-45). Ankara: Morpa.

Zigler, E., Gilliam, W. S., and Jones, S. M. (2006). A Vision For Universal Preschool Education. New York, NY: Cambridge University Press.

https:/ / doi.org/10.1017/CBO9781139167284

\section{Summary}

\section{Introduction}

Preschool education has become increasingly important due to changes in parenting and lifestyles and increased public awareness and accessibility to scientific studies. All parents wish their children to receive high quality and future-oriented education. Therefore, the physical facilities of schools, class size, teachers' competence, targeted behaviors and skills, and interaction with parents are becoming more and more critical (Ağgül Yalçın and Yalçın, 2018). Some criteria are of significant importance for the quality of preschool education and its positive impact on children's development (Can and Kılıç, 2019; Karademir and Ören, 2020). Those criteria are well-trained teachers, positive teacher-child interactions, class size, safe and rich environments that support language development, and curricula with social activities. 
The critical question is, "How can children reach high-quality preschool education?" High-quality preschool education depends on many factors; physical environment and materials, teacher and staff competence, class size, good teacherchild interactions, curricula, communication, and family training and engagement (Karademir and Ören, 2020) as well as a good working atmosphere (Epinosa, 2002; Aydagül, 2009; Wertfein, Spies - Kofler and Becker - Stoll, 2009).

All educational institutions must have a framework of quality to offer equal and high-quality preschool education. A framework of quality that meets the minimum standards makes education more efficient and accessible (World Bank Human Development Department [WBHDD], 2011). All stakeholders should be consulted to determine quality standards for preschool education (Güleş and Erişen, 2013). It is only competent teachers who can provide preschool education that supports children from different backgrounds. Teachers should receive high-quality training to acquire competence and should at least have an education degree from a college (Whitebook, 2003). Only well-trained teachers can offer high-quality preschool education. There is a considerable body of research on the effect of teacher competence and credentials on preschool education (LoCasale-Crouch et al., 2007). However, few studies investigate the effect of the competence of classroom assistants on the quality of preschool education.

Classroom assistants, also known as qualified instructors, class mothers, or caregivers, are education staff who work with students under the supervision of teachers. Classroom assistants help teachers organize activities and interact with students one-on-one during group activities and meet students' care needs. However, researchers and administrators do not play a role in the training of classroom assistants. The Turkish Preschool Education Institutions Regulation does not make it mandatory for schools to employ classroom assistants. However, schools in many countries employ classroom assistants to relieve teachers' workloads and help them with students' care needs. For example, almost all schools in the United States have at least one classroom assistant, depending on the class size (Sosinsky and Gilliam, 2011).

All stakeholders should be aware of the importance of high-quality preschool education. Research shows that the competence of school staff also affects the quality of preschool education. Therefore, this study investigated how teachers and school administrators thought the competence of classroom assistants affected the quality of preschool education.

\section{Method}

This was a case study that employed an embedded design to compare preschool teachers' and administrators' views on the quality of preschool education. A case study is employed to explore the views and experiences of a particular group on a current phenomenon (Yildırım and Simsek, 2012). Data were collected through semistructured interviews.

The sample consisted of six preschool teachers and five administrators of five primary schools and six preschool teachers and four principals of four kindergartens in the central district of Muş province. 
Data were collected through semi-structured interviews. The researchers developed semi-structured interview questions for teachers and administrators, each of whom were asked three questions during the interviews.

Data were analyzed using inductive content analysis. Researchers conduct inductive content analysis to encode and categorize the interview data, and then to develop themes and subthemes based on the relationship between those categories (Patton, 2014). All data answering the interview questions were grouped under the same codes. Themes and subthemes were developed, which were then reviewed to identify the relationship among them. The quotations/records were reread to check their compatibility with the codes, subthemes, and themes. The data were coded using QSR-Nvivo 8.

\section{Results and Discussions}

Despite the multitude of definitions, quality in preschool education depends on structural and functional interaction and combination (Canbeldek and Erdoğan, 2017; Morabito, Van de Gaer, Figueroa and Vandenbroeck, 2018; Zembat, 2007). The structural factors of quality in preschool education are class size, teacher-child ratio, and teachers' level of education and experience. The functional factors of quality in preschool education are children's interactions with caregivers and using materials and participating in activities that enhance learning (Canbeldek and Erdoğan, 2017).

Quality is not only about physical space and material but also about teacher competence, class size, teacher-student ratio, teacher-student interactions, curricula, communication, and parent education and engagement (Karademir and Ören, 2020). The teachers and administrators defined "quality" in a similar way to the literature.

Sevinç (2006) reported that mothers attached importance to the development of their children and made sure that schools and classrooms met specific standards (hygiene, safety, etc.). We found that mothers wanted schools to be safe, and the staff trustable. This result suggests that staff quality is vital in preschool education.

Balyer (2013) reported that principals gave importance to teaching, tried to set a good example for teachers, communicated with them effectively, gave them feedback and appreciated their work, and encouraged them to collaborate. Therefore, principals are an essential factor in the quality of education. Susmak and Hacıfazlıoğlu (2013) noted that preschool administrators should have teamwork skills and value people, and be consistent and supportive.

Quality in preschools depends on numerous interdependent factors. Just as space and material alone do not make a school a good school, the teachers or curriculum alone do not make education effective and productive. All elements of quality should interact harmoniously for the initiation and continuity of quality. The elements of quality are categorized into two groups: a) structural quality b) process quality (Epinosa, 2002; Zigler, Gilliam, and Jones, 2006). Structural quality depends on the class size, teacher-student ratio, and education level of teachers and administrators. Process quality depends on interaction, activities, materials, health, and safety (Epinosa, 2002). The teachers and classroom assistants addressed many of the elements of quality in the literature but did not mention the class size and teacher-student ratio. However, our results on the importance of the interaction between teachers/classroom assistants and students are consistent with the 
literature. Shonkoff and Philips (2000) found that students who were encouraged by their teachers and peers were likely to learn better.

The results showed that classroom assistants not only helped teachers but also spent more time with students and worked with them one-on-one. Therefore, schools should employ classroom assistants who know about child development and love children and can communicate with them and other people effectively. Classroom assistant-teacher collaboration provides a productive environment where students achieve effective learning. This result is consistent with that reported by Karademir et al. (2017). Shim, Hestenes, and Cassidy (2004) also found that education in classrooms with teachers and classroom assistants was more effective than that in classrooms with two teachers with a hierarchical relationship and in classrooms with only one teacher. However, some studies report that teachers expect classroom assistants (with no field knowledge) to respect the hierarchy and focus only on the care and needs of students and not interfere with activities. Some of the administrators appreciated the relationship between classroom assistants and students and teachers but also argued that it must be within certain limits. Sosinky and Gilliam (2011) also reported that teachers found classroom assistants less useful in activities, but particularly useful in classroom organization and supervision of children.

Arlington Public Schools (2005) determined that teachers needed classroom assistants mostly to keep students safe. The teacher has to accompany a preschooler who needs to leave the classroom. Therefore, it is the classroom assistant who ensures safety in the classroom in the absence of the teacher. Another teacher stated that she would rather work with a classroom assistant to deal with more students rather than deal with fewer students by herself.

\section{Pedagogical Implications}

Quality is not only about physical infrastructure, but also about the staff involved in education and the learning environment. We can see that classroom assistants play a role in the quality of education. However, preschool administrators, teachers, and parents decide whether to employ classroom assistants or not. If a preschool hires a classroom assistant, parents have to pay her social security premiums and salary. This reality shows that stakeholders of education see classroom assistants important but do not appreciate them. There should be a classroom assistant (teacher, sister, mother) in each classroom for effective learning in particular, and for high-quality preschool education in general. The Ministry of National Education should recognize the profession of classroom assistant and demand that preschools hire a classroom assistant for every classroom. This profession may appeal to the graduates of the department of child development of girls' vocational high schools.

\section{Araştırmanın Etik Taahhüt Metni}

Yapılan bu çalışmada bilimsel, etik ve alıntı kurallarına uyulduğu; toplanan veriler üzerinde herhangi bir tahrifatın yapılmadığı, karşılaşılacak tüm etik ihlallerde "Cumhuriyet Uluslararası Eğitim Dergisi ve Editörünün" hiçbir sorumluluğunun olmadığı, tüm sorumluluğun Sorumlu Yazara ait olduğu ve bu çalışmanın herhangi başka bir akademik yayın ortamına değerlendirme için gönderilmemiş olduğu sorumlu yazar tarafından taahhüt edilmiştir. 


\section{Authors' Biodata/Yazar Bilgileri}

Abdulhamit KARADEMİR, 2011-2013 y1lları arasında Anadolu Üniversitesi Okul Öncesi Öğretmenliği Anabilim Dalı'nda yüksek lisans, ardından 2014-2017 yılları arasında Hacettepe Üniversitesi Eğitim Fakültesi Okul Öncesi Eğitimi Bölümü'nden doktora derecesi alarak mezun olmuştur. Okul iklimi, okul yönetimi, çocuklar ve oyun, öğretmen yetiştirme ve özellikle okul öncesi eğitimde fen ve matematik konularında çok sayıda ulusal ve uluslararası araştırma ve proje yayınlamıştır. 2017 yılından itibaren Muş Alparslan Üniversitesi Eğitim Fakültesi Okul Öncesi Eğitimi Anabilim Dalı'nda öğretim üyesi olarak görev yapmaktadır.

Abdulhamit Karademir received a master's degree from the Department of Preschool Teaching of Anadolu University between 2011 and 2013, and then a Ph.D. degree from the Department of Preschool Education of the Faculty of Education of Hacettepe University between 2014 and 2017. He has published several national and international research papers and projects on school climate, school management, children and play, teacher training, and especially on preschool mathematics education. He has been working as an academic at the Department of Preschool Education, Faculty of Education at Muş Alparslan University since 2017.

Berrin AKMAN, erken çocukluk eğitimi konusunda uzmanlaşmış bir akademisyendir. Halen Hacettepe Üniversitesi Okul Öncesi Eğitimi Anabilim Dalı Başkanı olarak görev yapmaktadır. Başarılı araştırma kariyerinde, çocuk gelişimi, erken müdahale, okula hazırlık, fen ve matematik eğitimi, sınıf yönetimi, değerlendirme ve erken okuryazarlık konularında sayısız makale ve bildiri yayınladı. Yedi yıl Türk Eğitim Derneği Bilim Kurulu Başkanlığı yaptı. UNICEF ile işbirliği içinde, okul öncesi eğitimi ve erken okuryazarlığı güçlendirme konularında akademik danışman, çocuk tanıma ve değerlendirme uzmanı ve proje koordinatörü olarak görev yaptı. Profesör Akman, Şubat 2019'da bir yıl boyunca UC Berkeley'de misafir profesör olarak bulundu. Ahlaki gelişim ve değerler eğitimi üzerine Profesör Elliot Turiel ile çalıştı. Çocuk Gelişimi Araştırmaları Derneği, Türkiye Erken Çocukluk Eğitimini Geliştirme Derneği ve Türk Eğitim Derneği üyelikleri bulunmaktadır.

Berrin Akman is an academician specialized on early childhood education. She is currently the Chair of Division of Early Childhood Education at Hacettepe University, where she completed her B.S., M.S. and Ph.D. In her prosperous research career, she has published countless articles and conference papers on child development, early intervention, school readiness, science and math education, classroom management, assessment and early literacy. She was the Head of the Scientific Committee of Turkish Education Association for seven years. In collaboration with UNICEF, she served as an academic advisor, specialist on child assessment and evaluation as well as project coordinator in matters of strengthening pre-school education and early literacy. Professor Akman was visiting professor at UC Berkeley for one year in February 2019. She worked with Professor Elliot Turiel on moral development and values education. She holds memberships in Society for Research in Child Development, Association for the Development of Early Childhood Education in Turkey and Turkish Education Association. 